\title{
Institutions, Financial Frictions and Investment: Estimation with Structural Restrictions
}

\author{
Stijn Claessens ${ }^{*}$, Kenichi Ueda ${ }^{+}$, and Yishay Yafeh $^{\perp}$
}

March 2013

\begin{abstract}
We investigate how, by affecting financial frictions, country-specific institutions (such as shareholder and creditor rights) influence firm-level investment decisions. Using a structural model, we investigate two channels for the effects of institutions: on the cost of capital at the firm (micro) and on the required rate of return at the country (macro) level. Using a panel of 75,000 firm-years from 48 countries over the period 1990-2007, we find that: (i) countrylevel institutions affect firms' investment behavior; (ii) shareholder rights affect financial frictions and investment more than other institutions (e.g., product market competition, creditor rights) do; and (iii) the effects are especially pronounced for small firms with large financing needs, suggesting that stronger shareholder rights lead to a more efficient allocation of capital. These results suggest that improved corporate governance is key for reducing productivity dispersion across firms and foster economic growth.
\end{abstract}

JEL Classification Numbers: G30, O16, O43

Keywords: Financial friction, investment, Tobin's Q, institutions, investor protection

Acknowledgments and Disclaimer: We would like to thank Toni Braun, Murillo Campello, Giovanni Favara, Joe Kaboski, Ivo Krznar, Akito Matsumoto, Alex Monge, Ken Singleton, Ken West, Jeff Wooldridge, and seminar participants at the Bank of Japan, the IMF, Michigan State University, Pennsylvania State University, and George Washington University, as well as conference participants at the Dubrovnik Economic Conference, the Society for Economic Dynamics Conference in Montreal, the $10^{\text {th }}$ Econometric Society World Congress, and the Financial Underpinnings of Macro Models Workshop at MIT for helpful comments. We are grateful to Zeynep Elif Aksoy and Mohsan Bilal for excellent research assistance. This project was initiated while Yafeh was a Visiting Scholar at the IMF Research Department and completed while Ueda was visiting the Department of Economics, MIT. Yafeh would also like to thank the Krueger Center for Research in Finance at the Hebrew University for its support. The views expressed in this paper are those of the authors and should not be attributed to the International Monetary Fund, its Executive Board or its management.

\footnotetext{
* Research Department, IMF, 700 19th Street N.W., Washington, DC 20431, U.S.A, University of Amsterdam, CEPR, and ECGI. Email: sclaessens@imf.org

+ Research Department, IMF, 700 19th Street N.W., Washington, DC 20431, U.S.A. Email: kueda@imf.org

${ }^{\perp}$ School of Business Administration, The Hebrew University, Mount Scopus, Jerusalem 91905, Israel, CEPR, and ECGI. Email: yishay.yafeh@huji.ac.il
} 


\section{INTRODUCTION}

Financial frictions have long been identified as key factors driving both short-run economic fluctuations and long-run growth. Many theoretical models imply that, by reducing financial frictions, a country can enhance its investment efficiency, resulting in higher growth and lower volatility. More recently, research has explicitly investigated how relaxing financing constraints can contribute to reduced productivity dispersion and higher growth, especially for developing countries. ${ }^{1}$ Within this context, natural questions that arise are which financial frictions matter most and which institutional reforms can be most effective in reducing these frictions? While past research has addressed this question, most of the existing literature has relied on reduced-form regressions of investment on institutions (controlling for other variables). This, we argue, is not the most appropriate technique.

We develop therefore a novel estimation strategy with limited structural restrictions to assess the extent to which institutions affect financial frictions and, in turn, investment. We apply our approach to a large data set of listed firms with about 75,000 firm-year observations from 48 major advanced and emerging market economies over the period 19902007. We find three key results: first, institutions affect financial frictions and in turn investment; second, shareholder rights affect financial frictions more than institutions such as product market competition or creditor rights; and, third, the effect of shareholders rights is

\footnotetext{
${ }^{1}$ Hsieh and Klenow (2009) show that dispersion in productivity is larger among firms in developing countries than in advanced countries, with possibly reduced economy-wide productivity. Some attribute this higher dispersion to tighter credit constraints in developing countries. For example, Buera, Kaboski, and Shin (2011) show that collateral constraints combined with heterogeneous talents among entrepreneurs can explain productivity dispersion and how it improves with development. Better selection of productive activities by entrepreneurs along the development path is also shown to relate to a wider availability of financial services (Townsend and Ueda (2006, 2010) and Greenwood, Sanchez, and Wang (2010, 2013)).
} 
especially pronounced for small firms with large financing needs, suggesting that good corporate governance leads to a more equal access to finance. ${ }^{2}$

We start our analysis by modifying the standard investment model of Abel and Eberly (1994) to incorporate financial frictions in ways similar to Gomes (2001) and Hennessy, Levy, and Whited (2007). We then allow institutions to affect financial frictions via two channels. One channel relates institutions (e.g., investor protection) to firm-specific transaction costs associated with external finance (with costs also to vary with firm characteristics, such as industry and size). A second channel arises as the first component of the rate of return required by investors, the country-specific cost of capital depends on country-level institutions sum of a and a firm-specific risk premium, where and the second on firm characteristics.

Using the model, we show that, a priori, the effects of institutions on changes in $Q$ are ambiguous. As in Tobin (1969), high $Q$ firms should add capital, since the value of new capital goods exceeds its cost, and low $Q$ firms should shed capital. With no uncertainty, investment (or disinvestment) should bring $Q$ back to its equilibrium level every period (with shocks, the actual value of $Q$ will vary, but average movements will still be predictable given current $Q$ and profits). When current $Q$ is low (high), it can be expected to increase (decrease), implying a capital gain (loss) to investors. The sum of this capital gain (loss) plus

\footnotetext{
${ }^{2}$ Borrowing constraints are known to be important for unlisted small firms, especially startups (Cagetti and De Nardi, 2006, Paulson and Townsend, 2008, and Klapper and Love, 2011); in addition, some studies document a "debt overhang problem" for listed companies in the U.S. (Hennessy, et al. 2007). However, only a "horse race" study like ours can gauge the relative importance of the debt and equity channels of financial frictions. To the extent that significant financial constraints persist for listed firms, their ability to grow would be limited, in line with the findings of Hsieh and Klenow (2012).
} 
current profits (both properly scaled) has to equal the required rate of return. $Q$ will therefore converge less towards its next-period expected value in countries with low required rates of return, hypothesized to be brought about by good institutions. By contrast, to the extent that good institutions are associated with low firm-level transaction costs, $Q$ will tend to adjust rapidly in such countries. Since the two effects run in opposite directions, the overall relation between institutions and the adjustment speed of $Q$ is ambiguous.

While this ambiguity makes reduced-form regressions - of measures of countries' institutional development on the speed of adjustment in $Q$ - of limited value, we develop an empirical methodology which can be used to determine the effects of various institutions on financial frictions through the two channels described above. Specifically, in every year, we relate the differences at the firm level between predicted and realized values of $Q-$ i.e., oneperiod-ahead forecast errors - to structural parameters linking institutions to each channel. Using this structural model, the information contained in the movement of $Q$ over time for a large firm-level data set and the variation in institutional differences across countries, we can then robustly identify those institutions which are especially important in driving frictions. We show that this methodology provides unbiased estimators and confirm that the results are robust to measurement and specification errors. The latter is important because $Q$ is often considered a "noisy" measure of firm value (e.g., due to stock market inefficiencies or poor accounting information). Measuring institutional differences can also be challenging. In addition, any structural model may be subject to specification errors. We develop a test to identify the size of possible measurement and specification errors and show that these errors are negligible compared to the one-period-ahead forecast errors. In addition, we conduct a battery of traditional robustness tests and find that our results hold. These robustness checks 
indicate that our approach to estimating a structural investment model with financial frictions is an improvement over other estimation methods (e.g., Erickson and Whited, 2000).

Our work relates closely to a large literature which documents that institutions, especially those related to the financial system, help explain countries' financial and economic development and productivity (see reviews by Morck, Wolfenzon, and Yeung, 2005; Demirguc-Kunt and Levine, 2001; Levine, 2005; and La Porta, Lopez-de-Silanes, and Shleifer, 2008). This line of research, however, typically relies on reduced-form regressions relating a country's growth or development to financial and institutional development variables (e.g., Beck, Levine, and Loayza, 2000; De Nicolo, Laeven, and Ueda, 2008). Also related are industry-level studies, such as Rajan and Zingales (1998) and many subsequent papers, which show that industries more dependent on external finance tend to grow faster in countries with more developed financial systems and institutions. For example, Wurgler (2000), using a measure of industry-specific investment opportunities derived from growth in value added, shows that financially more developed countries allocate more capital to growing industries and less to declining sectors. Our study contributes to this research by introducing structural restrictions derived from first principles, thus helping identify channels by which institutions affect investment.

Our approach also overcomes the identification problem associated with standard investment-cash flow regressions. Starting with Fazzari, Hubbard, and Petersen (1988), many studies have proxied for credit constraints using the sensitivity of investment to firm cash flows, while controlling for growth opportunities using the firm's $Q$. However, as Gomes (2001) shows, with financial transaction costs, such regressions face serious identification problems since $Q$ reflects not only growth opportunities but also frictions (e.g., external 
financing constraints). Furthermore, with auto-correlated productivity shocks ("growth opportunities"), current profits contain information on future profitability, in addition to the availability of financing, thereby potentially biasing results.

To overcome the identification problem, some recent studies have modeled frictions (e.g., asymmetric information or limited contract enforcement) from first principles. Empirical applications of these models, however, have proven difficult, in part due to computational challenges. So far, studies have largely relied on calibration exercises (e.g., Lorenzoni and Walentin, 2007) or simulation-based estimations using restricted samples and limited control variables (Karaivanov, et. al. 2010). Accordingly, it is difficult for such models to statistically compare the relative importance of various financial frictions. An alternative approach, on which we build, is that of Hennessy, Levy, and Whited (2007) who include generic transaction costs and then identify the presence of such costs using data for large US firms. This literature, however, typically studies a single country with welldeveloped institutions (mostly the U.S.), whereas we explore the cross-country dimension. ${ }^{3}$

A closely related paper is McLean, Zhang, and Zhao (2012). They argue that, if cash flow sensitivity of investment proxies for growth opportunities, then growth should be higher in countries with higher cash flow sensitivity; but if it reflects credit constraints, then growth should be higher in countries with low cash flow sensitivity. While they find evidence for the latter conjecture, this does not necessarily imply that institutions affect investment by mitigating constraints on access to external finance ("credit constraints"). As shown by

\footnotetext{
${ }^{3}$ In addition, our estimation method differs from theirs.
} 
Gomes (2001), and in our model, $Q$ always reflects both effects. ${ }^{4}$ Finally, our paper relates to models of macro-finance fluctuations, where frictions are used to explain endogenous fluctuations in investment, which, in turn, create or amplify macroeconomic cycles. ${ }^{5} \mathrm{We}$ contribute to this literature by providing firm-level evidence on the effects of frictions. Our finding that good corporate governance matters primarily for firms with large financing needs, and therefore improves capital allocation across firms, sheds light on a source of investment inefficiency. It relates to Hsieh and Klenow (2009) who find a much larger dispersion in the (ex post) marginal product of capital for industrial plants in China and India than in the U.S. They interpret this as evidence of a more efficient allocation of capital in the U.S. (although with only three countries in their sample any assessment of the causes of this difference in efficiency is difficult). Also related is Abiad, Oomes, and Ueda (2008) who show that, under certain conditions and controlling for industry and age effects, the cross-sectional dispersion of $Q$ can proxy the ex ante efficiency of capital allocation, which in turn improves with financial liberalization. While their measure captures within-country

\footnotetext{
${ }^{4}$ If the credit-constraints effect always dominates the growth-opportunities effect, then a positive cash flow sensitivity can be interpreted as evidence of credit constraints. This does not necessarily hold, however, even if the growth-opportunities effect dominates on average. Suppose that the growth-opportunities effect is stronger in booms but that the credit-constraints effect is stronger in recessions. In this case, there will be a positive association between high cash flow sensitivity and low growth on average. But it does not necessarily follow that institutions affect credit constraints. Suppose that institutions affect investment only through the growth opportunities channel; in this case, better institutions will imply a higher cash flow sensitivity of investment, but at the same time there will be a positive association between high cash flow sensitivity and low growth. ${ }^{5}$ Kiyotaki and Moore (1997), assuming a simple collateral constraint, explain that drops (increases) in asset values lead to tighter (more relaxed) credit conditions. Bernanke and Gertler (1989) show how costly-stateverification (in the spirit of Townsend, 1979), an informational friction, amplifies productivity shocks by affecting investment. Motivated by the recent crisis, Gertler and Kiyotaki (2010) show how misconduct by bank managers can create principal-agent problems, which, in turn, alter firm investment and generate economic cycles. Some empirical work has explicitly investigated the validity of these assumptions, but using aggregate data (e.g., Chari, Kehoe, and McGrattan, 2006; Christiano, Motto, and Rostagno. 2010).
} 
effects of policy changes, it is less useful for cross-country comparisons, in part because it assumes a steady-state dispersion of Q which is likely to be country-specific. Related is also Acharya, Imbs, and Sturgess (2011), who show that, following financial deregulation, U.S. states moved closer to an efficient mean-variance frontier of industrial outputs. Such a measure cannot be used easily for cross-country comparisons, however, as specialization due to comparative advantage, presumably reflected in international trade, leads to countryspecific frontiers.

The paper proceeds as follows. Section II presents the model; Section III describes the estimation strategy; Section IV presents the main results; Section V examines measurement errors; and Section VI concludes.

\section{Theoretical Model}

We develop a theory-based law-of-motion for $Q$, which incorporates the effect of institutions on financial frictions and on capital adjustment, and derive structural restrictions for our empirical estimation procedures. Our discrete-time model closely follows the wellknown investment models of Hayashi (1982), Abel and Blanchard (1986), and Abel and Eberly (1994) and introduces financial frictions using a generalized version of the models of Gomes (2001) and Hennessy, Levy, and Whited (2007).

The value function for the optimizing firm can be expressed as follows (see Appendix I for the derivation):

$$
(1+r) V\left(K^{-}, \varepsilon\right)=\max _{K} \pi(K, \varepsilon)-\phi(I, K, \varepsilon)-\lambda(B, K, \varepsilon)+E\left[V\left(K, \varepsilon^{+}\right) \mid \varepsilon\right],
$$


where $r$ denotes the required rate of return, $K$ - capital, $\pi$ - profit, $I$ - investment, $B$ - external finance (the sum of equity finance, bond finance, bank debt, and trade credit), and $\varepsilon$ - a productivity shock, which can be auto-correlated. The minus-sign in the superscript denotes one-period-past and the plus-sign one-period-ahead values. Note that the value function's state variables are capital accumulated in the last period, $K^{-}$, and the current profitability shock, $\varepsilon$.

There are two adjustment costs: $\phi$, the (real) adjustment cost of investment and $\lambda$, the adjustment cost of external finance. The former is standard in the investment literature (e.g., Abel and Eberly, 1994), and assumed to be linear, quadratic and homogeneous of degree one in investment and capital: ${ }^{6}$

$$
\phi(I, K, \varepsilon)=c_{1} I+c_{2} K+\frac{c_{3}}{2}\left(\frac{I}{K}\right)^{2} K .
$$

The latter is similarly assumed to be linear, quadratic and homogeneous of degree one in external finance and capital, and is thus a generalized version of the specification used in several models with financial frictions (e.g., Gomes, 2001):

$$
\lambda(B, K, \varepsilon)=b_{1} B+b_{2} K+\frac{b_{3}}{2}\left(\frac{B}{K}\right)^{2} K .
$$

The first order condition yields a formula which we use in our empirical tests:

\footnotetext{
${ }^{6}$ Although there is no "pure" fixed cost in (2), the terms involving the capital stock, $K$, can be seen as reflecting costs which are proportional to firm size regardless of the size of investment. Note that the real business cycle literature with representative agents uses a convex adjustment cost for increases in investment, not for investment itself, in order to achieve smooth investment patterns over time. Although aggregate investment movement is relatively smooth, firm level investment is known to vary considerably. Therefore, in a firm level study as in this paper, adjustment costs are commonly defined in terms of investment, not in terms of increases in investment (for a reconciling effort, see Khan and Thomas, 2008).
} 


$$
E[Q \mid \varepsilon]=(1+r+\delta) Q^{-}-\left(1+\lambda_{1}\right) \pi_{1}+\phi_{2}+\lambda_{2}
$$

where $Q$ denotes the derivative of firm value $V$ with respect to capital $K$ (i.e., marginal value of capital); and the terms $\lambda_{1}$ and $\lambda_{2}$ denote the derivatives of $\lambda$ with respect to the first and second element (i.e., $B$ and $K$ ), respectively. The financial transaction costs are incurred only when external finance is actually used. When external finance is not positive, the marginal financial transaction costs, the terms $\lambda_{1}$ and $\lambda_{2}$, vanish. Similarly, when investment is not positive, the investment adjustment costs are zero and the $\phi_{2}$ term drops from (4). ${ }^{7}$

Note that the first order conditions refer to the marginal $Q$, the derivative of firm value with respect to capital. The marginal $Q$ can differ from the average $Q$, the ratio of firm value to assets. We follow most of the investment literature (e.g., Hayashi, 1982) and assume that the adjustment cost of investment is a linearly homogeneous of degree one function in investment and capital. Similarly, financial transaction costs, $\lambda$, are assumed to be a linearly homogeneous of degree one function in external finance and capital. Under these fairly general and standard assumptions, Hayashi's result that the marginal value of $Q$ equals the average value of $Q$ still holds. ${ }^{8}$

\footnotetext{
${ }^{7}$ Although it ignores the potentially important effect of costly disinvestment, this assumption is in line with much of the literature, (Abel and Eberly, 1994; Abel, Dixit, Eberly, and Pindyck, 1996). One reason for this omission is that information on asset sales is not widely available for countries other than the U.S.

${ }^{8}$ The formal proof, omitted here, is based on a system of homogeneous-of-degree-one functions, studied in Alvarez and Stokey (1998). Given competitive wages and product price (normalized to one), labor immediately adjusts to its optimal level. Because the production function exhibits constant returns to scale in capital and labor, profits become linear in capital given wages and product prices. Because adjustment costs are homogeneous of degree one in investment and capital and financial frictions are homogeneous of degree one in external finance and capital, the optimal amounts of investment and external finance become linearly proportional to capital. The value of the firm is therefore linearly proportional to capital as well, and hence marginal $Q$ equals average $Q$.
} 
Because of constant returns to scale, firm size does not matter in this model at the steady state. We do allow firm size to matter out of steady state, however. On the financing side, for example, a firm that has large financing needs relative to its capital stock, due to a large negative shock or because its initial capital stock is smaller than in the steady state, may pay higher financing fees. Moreover, this premium may vary across countries with the quality of institutions. In Equation (4), we allow for such large-financing premium in the form of the parameter $\lambda_{2}$ (the derivative of financial transaction costs with respect to capital).

\section{ESTIMATION METHODOLOGY}

\section{A. Minimizing One-Period-Ahead Forecast Errors}

To capture the effects of various institutions on financial transaction and investment adjustment costs, we hypothesize these costs to be linear functions of firm characteristics, $X$ ( $n \times k_{1}$ matrix, with $n$ being the number of firm-year observations and $k_{l}$ the number of firm characteristics $)$, and country institutions, $W\left(n \times k_{2}\right.$ matrix and with $k_{2}$ being the number of institutional variables). We can then rewrite Equation (4) as:

$E[Q \mid \varepsilon]=X \gamma_{1}+W \gamma_{2}+Q^{-} \alpha_{1}+\left(X^{*} Q^{-}\right) \alpha_{2}+\left(W^{*} Q^{-}\right) \alpha_{3}+Z \beta_{1}+\left(X^{*} Z\right) \beta_{2}+\left(W^{*} Z\right) \beta_{3}$.

where $Z=\left[\begin{array}{llll}-\pi_{1} & -\lambda_{1} \pi_{1} & \phi_{2} & \lambda_{2}\end{array}\right]$ (an $n \times 4$ matrix), $\left(X^{*} Z\right)$ is the interaction term between $X$ and $Z$ (an $n \times 4 k_{1}$ matrix), and likewise for the other interaction terms. Taking expectations over the next period's shock, $\varepsilon^{+}$given the current period's shock, $\varepsilon$, yields the expected values for the next-period $Q$.

In the data, we only observe the realized values of the next-period $Q$. The difference between the expected and realized values is the one-period-ahead forecast error: 


$$
\xi=Q-E[Q \mid \varepsilon] .
$$

This one-period-ahead forecast error is serially uncorrelated even if the underlying productivity shocks are serially correlated, making OLS estimates unbiased and consistent.

While the average value of productivity shocks is zero and shocks are uncorrelated with institutions, expected productivity levels may well be correlated with country-specific institutions. For example, R\&D outlays may be limited because of credit constraints resulting from poor creditor rights. These level effects should be reflected in both current and future $Q s$. That is, both the average level of $Q$ and its serial correlations are affected by institutions, but the expected forecast errors of $Q$ should not be affected and serially correlated. Nevertheless, the covariance of forecast errors could be affected by institutions, although the direction is ambiguous (for example, weak institutions may induce low R\&D intensity resulting in a small variance for firms or may cause more frequent booms and busts, resulting in a large comovement across firms). Regardless, we allow for the possibility that firm observations within a country in a given year are subject to correlated shocks (e.g., booms and busts) by using robust standard errors with clustering at the country-year level.

\section{B. Estimation Equation}

The required rate of return, $r$, is treated as a linear function of firm characteristics, $X$, and of country-specific institutional factors, $W$. This is captured in the coefficients $\alpha_{1,} \alpha_{2}$, and $\alpha_{3}$ on lagged $Q$ in Equation (5), denoted here as a coefficient vector, $a(X, W)$. We write the other coefficients describing investment adjustment costs and financial transaction costs, $b_{l}$, $b_{2}, b_{3}, c_{2}$, and $c_{3}$ similarly as vector functions. 
We can now derive the benchmark estimation equation of movements of $Q$, as in Equation (6) below. It is a reformulation of Equation (5). Because in our model, we do not differentiate between kinds of capital - the firm maximizes profit given its capital broadly defined - we use Total Assets, $A$ (which includes among others both physical capital and liquid assets) instead of fixed capital $K$, as the measure of the firm's capital.

$$
\begin{aligned}
Q_{i, j, k, t} & =\kappa \pi_{1, i, j, k, t}+\gamma\left(X_{j, k, t}, W_{k}\right)+a\left(X_{j, k, t}, W_{k}\right) Q_{i, j, k, t-1} \\
& -b_{1}\left(X_{j, k, t}, W_{k}\right) \pi_{1, i, j, k, t} \chi_{i, j, k, t}+b_{2}\left(X_{j, k, t}, W_{k}\right) \chi_{i, j, k, t} \\
& -b_{3}\left(X_{j, k, t}, W_{k}\right)\left\{\left(\frac{B_{i, j, k, t}}{A_{i, j, k, t}}\right) \pi_{1, i, j, k, t}+\frac{1}{2}\left(\frac{B_{i, j, k, t}}{A_{i, j, k, t}}\right)^{2}\right\} \chi_{i, j, k, t} \\
& +c_{2}\left(X_{j, k, t}\right) \Psi_{i, j, k, t}-c_{3}\left(X_{j, k, t}\right)\left(\frac{I_{i, j, k}}{A_{i, j, k, t}}\right)^{2} \Psi_{i, j, k, t}+\xi_{i, j, k, t},
\end{aligned}
$$

where the second term $\gamma\left(X_{j, k, t}, W_{k}\right)$ controls for level effects, including country and industry fixed effects. The two indicator functions are defined as:

$$
\begin{aligned}
\chi_{i, j, k, t} & =1, \text { if } B_{i, j, k, t}>0 ; \\
& =0, \text { otherwise; and } \\
\Psi_{i, j, k, t} & =1, \text { if }=\mathrm{I}_{i, j, k, t}>0, \\
& =0, \text { otherwise. }
\end{aligned}
$$

The marginal return to capital is calculated as:

$$
\pi_{1, i, j, k, t}=\frac{\pi_{i, j, k, t}-\pi_{i, j, k, t-1}}{A_{i, j, k, t}-A_{i, j, k, t-1}}
$$

The specific institutions we use are corporate governance, referring primarily to shareholder rights (CorpGov), creditor rights (Creditor), general institutional quality such as property 
rights (Institution), product market competition (Compet), and financial market development (FinMkt). The level effect $\boldsymbol{\gamma}$ (which includes country fixed effects) is then defined as:

$$
\begin{aligned}
\gamma\left(X_{j, k, t} W_{k}\right)= & \sum_{k} \gamma_{0 k} \text { CountryDummy }_{k} \\
& +\sum_{j} \gamma_{1 j} \text { IndustryDummy }{ }_{j}+\gamma_{2} \text { Age } e_{i, j, k, t} \\
& +\gamma_{3} \text { RiskFreeRate }_{k}+\gamma_{4} \text { Inflation }+\gamma_{5} \text { Macro } \\
& +\gamma_{6} \text { CorpGov }+\gamma_{7} \text { Creditor }+\gamma_{8} \text { Institution }+\gamma_{9} \text { Compet }+\gamma_{10} \text { FinMkt } .
\end{aligned}
$$

And the interaction terms with lagged $Q$ can be expressed as:

$$
\begin{aligned}
a\left(X_{j, k, t} W_{k}\right)= & \sum_{j} a_{1 j} \text { IndustryDummy } \text { In }_{j}+a_{2} \text { Age }_{i, j, k, t} \\
& +a_{3} \text { RiskFreeRate }_{k}+a_{4} \text { Inflation }+a_{5} \text { Macro } \\
& +a_{6} \text { CorpGov }+a_{7} \text { Creditor }+a_{8} \text { Institution }+a_{9} \text { Compet }+a_{10} \text { FinMkt },
\end{aligned}
$$

where Macro refers to macroeconomic volatility, which is a control variable at the country level together with the risk free rate and inflation. Firm characteristics (industry and age effects) are also controlled for. The coefficients on the other, interaction terms $\left(\boldsymbol{b}_{1}, \boldsymbol{b}_{2}, \boldsymbol{b}_{3}, \boldsymbol{c}_{2}\right.$, and $c_{3}$ ) take the same form.

The effects of institutions on the financial transaction cost and the required rate of return functions can now be identified from the interaction terms. Institutional variables are assumed to be time invariant and therefore all the level effects associated with institutions are absorbed in the country fixed effects. The coefficients for investment and external finance are identified because they differ in magnitudes. ${ }^{9}$ In addition, investment adjustment costs need not be influenced directly by current profits, whereas financing is, and therefore only external finance is interacted with profits (coefficients $b_{1}$ and $b_{3}$ ). We also assume that institutional

\footnotetext{
${ }^{9}$ For example, positive investment does not necessarily require positive external finance, as firms may finance investment internally. Also, firms with negative profits and no investment may still seek external funds for working capital needs or in order to maintain their capital.
} 
factors do not affect the technological adjustment of investment in the benchmark specification, although we revisit this issue later.

Given the expected next-period $Q$, the higher the marginal cost of external finance (i.e., the higher are $b_{1}$ and $b_{3}$ ), the higher will the current-period $Q$ be. This reflects tighter financing constraints and the associated lower level of investment (Equation (4)). On the other hand, given the current-period $Q$, the expected next-period $Q$ will be lower. This is similar to what is implicitly assumed about cash flow sensitivity in a typical investment regression, except that our model allows for more precise estimation of financial frictions.

\section{ESTIMATION RESULTS}

The specific variables we use are presented in Table 1a and described in detail in Appendix II. Table 1b shows the correlation matrix among the variables. In particular, to capture country-level institutions, $W$, we use several measures, covering both the de jure and de facto institutional arrangements which could be related to financial transaction costs and the required rate of return. For the five institutional dimensions, we employ various measures. In the benchmark regression, we use for the quality of corporate governance (CorpGov) the shareholder (anti-director) rights (La Porta et al., 1998), a measure commonly used in the literature on investor (shareholder) protection. For creditor rights (Creditor), we use the strength of legal protection for lenders and borrowers (World Bank, 2008a). We use the property rights measure of La Porta et al. (1998) as a proxy for general institutional quality (Institution). For product market competition (Compet), we use a measure of trade barriers (World Economic Forum, 2007). For financial development (FinMkt), we use stock market-capitalization-to-GDP for 2005 (World Bank, 2008b). 


\section{A. Interpreting the Results}

Before presenting the regression results, we review the interpretation of the coefficients. The partial derivatives of the investment adjustment and financial transaction cost functions determine the equilibrium law of motion of $Q$ as in Equation (4). In particular, the coefficients $b_{1}, b_{2}, b_{3}, c_{2}$, and $c_{3}$, determine the evolution of $Q .{ }^{10}$ As we show below, in the regressions, we find the coefficient values to be as follows: $b_{1} \approx 0, b_{2} \approx 0$, and $b_{3}>0$. This means that the transaction cost function is increasing in the amount of external finance $B$ (i.e., $\left.\lambda_{1}=b_{1}+b_{3}(B / K)>0\right)$. It also means that, the lower $b_{1}$ and $b_{3}$ are, the lower are the marginal financial transaction costs.

The coefficient $b_{2}$ represents the extent to which the cost function is decreasing in capital, $K$, given the size of the firm's financing needs $B$ (i.e., $\left.\lambda_{2}=b_{2}-b_{3}(B / K)^{2}<0\right)$. This coefficient thus represents the additional costs borne by firms in need of large financing relative to their size (i.e., where $B$ is large relative to $K$ ). Because the production and cost functions are of constant returns to scale, a small capital stock relative to the firm's financing needs indicates that the firm is in a growth phase or has a small capital stock after the realization of a bad shock.

As illustrated in Figure 1, the larger $b_{2}$ is, the more firms pay for external financing. While a large $b_{2}$ means higher costs for all firms, the relative cost increase as $b_{2}$ increases is

${ }^{10}$ The partial derivative of the adjustment cost function with respect to capital is: $\phi_{2}=c_{2}-\frac{c_{3}}{2}\left(\frac{I}{K}\right)^{2}$. The partial derivatives of the financial friction function with respect to external finance and capital are: $\lambda_{1}=b_{1}+b_{3}\left(\frac{B}{K}\right)$ and $\lambda_{2}=b_{2}-\frac{b_{3}}{2}\left(\frac{B}{K}\right)^{2}$, respectively. 
smaller for firms with large external financing needs, that is, the large financing premium declines with increases in $b_{2}$. As such, a large $b_{2}$ is relatively good news for small firms because it means a more equal competition for funds. Stated differently, an increase in $b_{2}$ (due to institutional changes) could mean a more efficient capital allocation across firms because previously privileged firms (with a large capital stock and small financing needs) face relatively higher costs compared to smaller, growing firms.

In addition to the effect of institutions on the adjustment cost function's parameters, institutions may also affect the average cost of capital that all firms face through the link between the quality of a country's institutions and the required rate of return. We therefore estimate the total effect of institutions on financing costs and investment not only through the individual firm's transaction costs but also through the macro-required rate of return.

\section{B. Benchmark Regression}

Table 2 shows the benchmark regression results. Specifically, it shows the estimated coefficients for the interaction terms of interest, where each of the cells represent the interactions between the corresponding row (e.g., Corporate Governance) and column (e.g., lagged $Q$ representing Required Return). ${ }^{11}$

In the first column, the coefficient on lagged $Q$ captures the effects of institutions and firm variables on the required rate of return. Good corporate governance is negatively and significantly associated with the required rate of return, with a coefficient of -0.0433 . The

\footnotetext{
${ }^{11}$ Because the number of coefficients for the benchmark regressions with all the institutional variables is large, we do not present the other coefficients (e.g., country and industry fixed effects) or interaction terms involving industry dummies.
} 
magnitude of the effect can be interpreted as follows: a one-standard-deviation improvement (increase of 1.3) in corporate governance would lower $Q$ in the next period by 0.08 for the average firm (with a $Q$ of 1.5), i.e., a 5 percent larger adjustment (through bigger investment). More intense product market competition is associated with a higher required rate of return but this coefficient is only significant at the 10 percent level. Higher firm age is also associated with a higher rate of return but the effect is negligible. Other factors do not have an effect on the required rate of return.

The second to fourth columns present the effects of institutions and other variables on firm-level financial transaction costs. The second column shows how institutions affect the slope of the financial transaction cost function, or equivalently, the intercept of the marginal cost curve for raising external finance. The third column captures the differential effect of firm size or capital stock (i.e., the large financing premium). And, the fourth column shows the effect of institutions on the curvature of the financial transaction cost function, or equivalently, on the slope of the marginal cost curve. Note that the second and fourth columns are expected to have negative signs.

Good corporate governance (shareholder rights) increases the intercept of the marginal financial transaction cost curve (column 2), but the effect is small and significant only at the 10 percent level. Importantly, better corporate governance reduces the premium paid by firms with large financing needs (column 3). A one standard deviation improvement in corporate governance (1.3) lowers the large financing premium by about 3 percent of assets. Also, a one-standard-deviation improvement in general institutional quality (0.8) lowers the large financing premium by about 5 percent of assets. Good creditor rights seem to increase the large financing premium but the statistical significance of this result is limited 
and not robust to other specifications. Other factors do not have statistically significant effects on firm-level financial transaction costs.

Figure 2 illustrates the size effects on the financial transaction cost curve arising from the quality of corporate governance and general institutions. The negative slope means that firms with a large capital stock, $K$, relative to a given amount of external finance, $B$, pay less (the solid line). In a country where both corporate governance and general institutional quality are one-standard-deviation better than average, the financial transaction cost curve is located higher but it is also flatter (the dashed line). And when corporate governance and general institutional quality are one-standard-deviation below average, the cost curve is positioned lower but it is also steeper (the dotted line). ${ }^{12}$ While better corporate governance and property rights thus do not necessarily lead to lower absolute financial transactions costs, they do enable firms with large financing needs (low $K$, high $B$ ) to gain better access to finance relative to those with small financing needs.

Note that improved investor protection means, in addition to its effects on financial transaction costs, that the overall required rate of return is lower, so that all firms, including not-so-small ones may benefit in an absolute terms. Figure 3 illustrates how the overall effect of institutions on financial frictions varies for a hypothetical average firm with total assets of $K$ and borrowing needs of $B$, with one line (dashed) representing high and one line (dotted) for low quality of corporate governance. Within each country, firms with large financing needs (low $K$, high $B$ ) face relatively higher financing costs compared to firms with lower

\footnotetext{
${ }^{12}$ To draw the average line, we run a regression using, instead of institutional factors, simple country dummies, with the line plotted using the average coefficient. The two one-standard-deviation lines are drawn using the benchmark regression results regarding the effects of institutional factors on financial transactions costs.
} 
financing needs, as shown by the two downward sloping lines. Importantly, this cost differential is larger in countries with poor corporate governance. In a country with corporate governance one standard deviation below average, a firm with financing needs of only 20 percent of total asset $(K / B$ at 5$)$ pays about 50 basis points more than a firm with financing needs twice the size of its assets $(K / B$ at 0.5$)$. This cost difference is, however, only about 25 basis points, i.e., half the magnitude, in a country with corporate governance one standard deviation above average. For more extreme cases, this difference widens even more (as the cost function is convex). The overall effect of better institutions can thus be sizable.

\section{Interpretation in Terms of Adjustment Speed}

Our regression results can also be interpreted in terms of the speed of adjustment of $Q$. In a world without real or financial frictions, $Q$ should quickly converge to one. A financial system which is more efficient, however, does not always correspond to a faster adjustment of $Q$. With stochastic shocks, $Q$ fluctuates around its (conditional) expected value $E[Q \mid \varepsilon]$. The speed of convergence of $Q$ to its firm-specific expected value then depends on institutions, given the current capital stock and the past-period's productivity shock. In what we consider a new finding, institutional development affects the speed of adjustment in two opposing directions, making the overall relation ambiguous. To see, rewrite Equation (4) as:

$$
\frac{Q^{-}-E[Q \mid \varepsilon]}{Q^{-}}=\frac{\left(1+\lambda_{1}\right) \pi_{1}-\left(\phi_{2}+\lambda_{2}\right)}{Q^{-}}-(r+\delta) \text {. }
$$

Equation (7) shows that the distance between the current-period $Q$ and the expected nextperiod's $Q$ depends on the marginal financial transaction costs, $\lambda_{1}$, and the required rate of return, $r$ (as well as on other factors which are assumed not to vary with institutions). If good 
institutions are associated with both a low required rate of return and low financial transaction costs, then the effect of institutions on the adjustment speed is actually ambiguous. Hence, it is not always the case that in countries with good institutions $Q$ will adjust faster towards its expected value than in countries with poor institutions.

Using our coefficient estimates, we can show that $Q$ will actually be closer to its expected next-period value for firms in countries with good corporate governance. While a good overall institutional environment (property rights) does affect the overall required rate of return, differences between small and large firms in the adjustment speed of $Q$ are smaller in countries with a good institutional environment.

\section{Robustness Checks}

To verify that the results are not driven by the specific firm and country measures we use, we examine a number of alternative variables and proxies. We start with different measures for some of the firm level variables. In Table 3a, we use before-tax income rather than after-tax income. In Table 3b, we use a broader concept of investment, which includes, in addition to fixed capital investment, financial investments. In Table $3 c$, we use a narrower concept of external finance, excluding trade credit from the benchmark specification.

The regressions with these different accounting measures (Tables $3 \mathrm{a}-\mathrm{c}$ ) essentially replicate the benchmark results. A slight difference is observed when we use the narrower concept of external capital (Table 3c): here, the effects become less significant, except for the reduction in the large financing premium associated with better corporate governance. The

effects of real factors are not tabulated here (or in any following table) as they hardly differ from their effects in the benchmark regression. 
Next, we check if the effects of any individual institutional measure are affected by other factors which are correlated with it. We therefore estimate the effects of each institutional factor without including any other factor. Each row of Table 4 shows the corresponding one-by-one regression. The results are virtually the same as in the benchmark regression, except that the effects of product market competition and financial market development are significant, unlike in the benchmark regressions that include all the institutional factors at once. This suggests that the correlations among the institutional variables do not generally lead to an over- or under-estimation of the effects. In what follows, we continue to always include all five institutional factors, as in the benchmark regression.

We next examine alternative proxies for the institutional factors in Table 5, where each row presents the effect of one alternative institutional variable. The difficulty of coding the laws and regulations has led researchers to construct de facto, rather than de jure measures of corporate governance. When we use the anti-self-dealing index of Djankov, La Porta, Lopez-de-Silanes, and Shleifer (2008), which is based on surveys of lawyers and meant to reflect actual practices rather than law on the books (and is also more up-to-date), the benchmark results are mostly replicated, although in this specification corporate governance no longer matters for the required rate of return. We also examine the De Nicolo, Laeven, and Ueda (2008) measure of de facto corporate governance quality (CGQ) reflecting actual disclosure practices and transparency of firms at the country level. ${ }^{13}$ The benchmark

\footnotetext{
${ }^{13}$ This index measures country-level corporate governance using firm-level data in three dimensions: disclosure (number of accounting items disclosed), transparency (disparity of earnings between before and after accounting ad hoc adjustments), and stock price comovement. Following the results of Doidge, Karolyi, and
} (continued) 
results are, again, broadly replicated, except for the effect on the required rate of return. ${ }^{14} \mathrm{We}$ conclude that alternative corporate governance measures broadly support the conclusion that good corporate governance is associated with easier access to finance for small firms with (relatively) large financing needs.

As an alternative measure of creditor rights (Creditor), we use a variable that captures the ability of creditors to seize collateralized assets (Djankov, McLiesh, and Shleifer, 2007). We find that this variable is associated with a higher premium for firms with large financing needs, in contrast with most other regression results where a broader measure of creditor rights has low or little statistical significance. One interpretation of this result is that an increase in the ability of creditors to seize assets from borrowing firms proxies for strong bargaining power of lenders. In contrast with this finding, when we use a de facto, surveybased measure of the overall efficiency of bankruptcy procedures (from Djankov, Hart, McLiesh, and Shleifer, 2008) we find that the benchmark results hold, that is, there is no effect of creditor rights on the dynamics of $Q$.

As an alternative measure of general institutional quality (or property rights, Institution), we use the rule of law (from Kaufman, Kraay, and Mastruzzi, 2004) and trust in people (from the World Values Survey, worldvaluessurvey.org). Both of these variables are negatively associated with the large financing premium, as in the benchmark regression.

Stulz (2007) who find that country-level corporate governance matters much more than firm-level corporate governance, only country-level corporate governance measures are used.

${ }^{14}$ Note that the mean of the $C G Q$ index is five times smaller than the mean of the standard shareholder protection variable which is based on "anti-director rights," suggesting that the magnitudes of the coefficients here are much larger than in the benchmark regression. 
As alternative measures of product market competition (Compet), we use the degree of new business entry (World Development Indicators, 2008) and the cost of business startups (World Bank Doing Business, 2008). Easier entry is negatively associated with the large financing premium and low start-up cost is associated with a low curvature of the financial transaction cost function. The effects are similar to those we find for corporate governance. Indeed, these de facto measures may reflect the country-wide benefits associated with good corporate governance, namely product market competition and other country characteristics (e.g., financial development) that facilitate new firm entry and lower start-up costs.

As alternative measures of financial development (FinMkt), we use private credit to GDP and the absence of foreign ownership restrictions (both from World Economic Forum, 2007). These different measures hardly alter the benchmark regression results.

We also conduct robustness checks for our measure of macroeconomic volatility (Macro). When we use the coefficient of variation of the exchange rate and the standard deviation of inflation rate, both from the World Development Indicators, we find that the regression results are unchanged from the benchmark results (not tabulated).

Next, we check robustness to sample selection. Because Age is often missing, we exclude the Age variable from our regression and rerun the regressions with a sample that is almost double in size, 147,711 instead of 74,272 observations. The results are broadly similar to the benchmark results, except that corporate governance no longer matters for the required rate of return (not tabulated). The results remain unchanged when using either all the available non-financial firms or manufacturing firms only (not tabulated).

Overall, the benchmark results are broadly replicated in most regressions (including those not tabulated). Good corporate governance and general institutional quality are 
consistently related to easier access to finance by small and growing firms. In addition, good corporate governance is associated with a low required rate of return in many specifications. Other factors do not robustly affect either financial transaction costs or the required return.

\section{E. Real Adjustment of Investment and Institutions}

Institutional factors may affect the adjustment of investment not only by affecting financial frictions but also by changing real investment adjustment costs. ${ }^{15}$ We therefore examine if our main results remain unchanged if we allow institutional variables to affect also the coefficients that characterize the real adjustment costs of investment (not only the financial transaction costs). The results regarding financial transactions costs and the required rate of return remain virtually unchanged relative to the benchmark regressions (Table 6). ${ }^{16}$

\section{Measurement ERrors}

\section{A. Sources of Measurement Errors for Tobin's $Q$}

\section{Stock Price Movements}

Stock markets may not always reflect fundamental values (see e.g., Duffie, 2010). For the U.S., Abel and Blanchard (1986) address this issue by constructing a time series for $Q$ based on a long time series of past marginal products of capital. Philippon (2009) utilizes a

\footnotetext{
${ }^{15}$ Managerial entrenchment (e.g., Myers and Majluf, 1984, Gaudet, Lasserre, and Van Long, 1998) or worker sabotage (Parente and Prescott, 2000) may give rise to institutions affecting real investment adjustment costs.

${ }^{16}$ As for the effect of institutions on technological adjustment costs, we find that good corporate governance lowers the rate at which real costs increase with size $(c 2)$, where the size effect itself is presumably due to technological and managerial diseconomies of scale. However, this is somewhat offset by an increased slope of the marginal real adjustment cost curve: small new investments appear to have lower costs but big new investments have higher costs. Also, unlike the case of financial frictions, the intercept term is not identified econometrically. Overall, the effect of institutions on non-financial investment adjustment costs is not clear.
} 
long time series of corporate bond prices, also for US firms. Because our cross-country data are short in the time dimension and bond prices are often not available, we cannot utilize these strategies. Note that because stock prices are quite volatile, measurement errors in $Q$, if any, should exhibit little auto-correlation.

\section{Accounting Issues}

Accounting items are subject to measurement errors. We have already run several robustness checks using different proxies for major variables other than $Q($ Table $3 \mathrm{a}-\mathrm{c})$. We further address the possibility of mis-measurement of debt (in the numerator of $Q$ ) and of the replacement cost of capital (in the denominator) by using country fixed effects which can capture persistent measurement errors related to country-specific accounting conventions.

\section{Average versus Marginal $Q$}

The difference between the theoretical marginal and average values of $Q$ has long been recognized in the literature (Hayashi, 1982). As noted above, we follow conventional modeling assumptions so that the two values should coincide. However, as Hayashi (1982) shows, even with these assumptions, monopoly power in product markets may create a disparity between marginal and average $Q$. Moreover, as Abel and Eberly (2008) show, movements in $Q$ can become larger with monopoly power and with decreasing returns to scale. In our estimations, the coefficients on product market competition are not robustly related to changes in $Q$. This suggests that, at the country level, the average effect of monopoly power is small compared to other factors affecting the evolution of $Q$. Note that industry-specific movements, to the extent that they are due to monopolistic power, are controlled for since we include industry interaction terms. And within industry, any short- 
lived rents or monopolistic profits from, say, innovative products are captured by serially correlated productivity shocks.

\section{Different Timing Assumptions}

Timing assumptions are critical. Without the time-to-build assumption (i.e., with immediate use of capital after investment), investment would always adjust fully to any productivity shocks. In the special case of no "time-to-build" assumption, there would be no relationship between the last period's $Q^{-}$and the current $Q$, so that the coefficient $a$ would be zero (Barnett and Sakellaris, 1999). Our results show that this is not the case.

We can also consider different timing assumptions regarding the revelation of productivity shocks. So far, we have assumed that the productivity shock is revealed at the beginning of the current period, so that the last period's $Q^{-}$can be observed together with (information on) the current shock. As such, the setup is non-stochastic as of the beginning of the current period. It may be the case, though, that the shock is not (fully) revealed at the beginning of the current period. In this case, investment decisions will still be made after the shock is realized, but then we really observe $E\left[Q^{-} \mid \varepsilon^{-}\right]$, not $Q^{-}$itself. If so, there will be no observation errors in the next period's $Q$, as we can observe $E[Q \mid \varepsilon]$ in the data. However, there will be another form of forecast error in $Q$, which could be classified broadly as a measurement error: decisions are made on the basis of the realized value of $Q^{-}$but we only observe its forecasted value $E\left[Q^{-} \mid \varepsilon^{-}\right]$. Since these errors are one-period-ahead forecast errors, however, they should not exhibit any auto-correlation. 


\section{B. Testing for Measurement Errors}

All four forms of measurement errors possibly affect the observed values of $Q$. If

sizable measurement errors do indeed exist, then the OLS errors will exhibit serial

correlation. To see this, write the observed $Q$ (denoted with hat) as the sum of the true $Q$ and

the measurement error, that is, $\hat{Q}=Q+v$. Using (5), the errors can then be expressed as:

$$
u_{O L S}=(\xi+v)-\left\{v^{-} \alpha_{1 O L S}+\left(X * v^{-}\right) \alpha_{2 O L S}+\left(W^{*} v^{-}\right) \alpha_{3 O L S}\right\}
$$

where the measurement errors $v$ are assumed to have a mean of zero and to be serially

uncorrelated, that is, $E[v]=0$ and $E\left[v^{\prime} v^{-}\right]=0$. In this case, the OLS errors have serial

correlation equal to:

$$
E\left[u_{O L S}{ }^{\prime} u_{O L S}^{+}\right]=-\left\{E\left[v^{\prime} v\right] \alpha_{1 O L S}+E\left[v^{\prime}\left(X^{*} v\right)\right] \alpha_{2 O L S}+E\left[v^{\prime}\left(W^{*} v\right)\right] \alpha_{3 O L S}\right\}
$$

This is expected to be non-zero in the presence of measurement errors. If the measurement errors, $v$, are also serially correlated, more terms will be included in (9) and the serial correlation of the OLS errors is likely to be (even) larger.

By testing for serial correlation in the OLS errors, we can evaluate the severity of the measurement error problem. When we do so, we find that the null hypothesis of zero serial correlation in (9) cannot be rejected. ${ }^{17}$ In other words, measurement errors are very small compared to one-period-ahead forecast errors.

\footnotetext{
${ }^{17}$ Note that, by using fixed effects estimation, theoretically the regression errors $u$ have additional autocorrelation (see Wooldridge, 2002, p.275). If we use only the last year sample in our dataset, we need to test for autocorrelation in (8) against the theoretical null hypothesis, $-1 /(T-1)$, where the time dimension is $T=18$ in our case. We conduct this test correcting for potential heteroskedasticity and find the AR(1) coefficient of the fixed effect residuals to be 0.200 with a standard error of 0.162 . The theoretical autocorrelation is -0.059 ( $=-$ $1 / 17$ ) and the $t$-statistic is 1.64, i.e., not significant. Alternatively, if we use all the observations, we have to test (continued)
} 


\section{Measurement Errors in the Institutional Variables}

Measuring institutional quality is difficult and often subjective. In addition to checking the robustness of our results to alternative institutional proxies, we can consider measurement errors in the institutional variables $W$ (in addition to those in $Q$ ).

Suppose that the observed institutional indicators (denoted with hat) are measured with measurement errors $\omega$, that is, $\hat{W}=W+\omega$ with $E[\omega]=0, E\left[\omega^{\prime} v\right]=0$ and $E\left[\omega^{\prime} v^{-}\right]=0$. Then, the OLS errors are slightly different from (8):

$$
u_{O L S}=(\xi+v)-\left\{v^{-} \alpha_{1 O L S}+\left(X * v^{-}\right) \alpha_{2 O L S}+\left((W+\omega) * v^{-}\right) \alpha_{3 O L S}\right\}
$$

In this case, the OLS errors are again serially correlated even more than before:

$$
E\left[u_{O L S}{ }^{\prime} u_{O L S}^{+}\right]=-\left\{E\left[v^{\prime} v\right] \alpha_{1 O L S}+E\left[v^{\prime}\left(X^{*} v\right)\right] \alpha_{2 O L S}+E\left[v^{\prime}\left(W^{*} v\right)\right] \alpha_{3 O L S}+E\left[v^{\prime}\left(\omega^{*} v\right)\right] \alpha_{3 O L S}\right\}
$$

As shown above, however, serial correlation in the OLS errors is rejected and hence measurement errors in the institutional variables are unlikely to be large enough to affect the coefficient estimates.

\section{Instrumental Variable Estimation for Tobin's $Q$}

While measurement errors are likely to be small, we can nevertheless check the robustness of our findings to measurement errors by using instrumental variable estimation

for autocorrelation in (8) against the null of zero with robust errors to correct both for the theoretical possibility of varying serial correlations due to the fixed effect estimation, and for potential heteroskedasticity (again, see Wooldridge, 2002, p.275). We conduct this alternative test as well: the AR (1) coefficient is 0.050 with a standard error of 0.054 and the $t$-statistic is 0.91 , again not significant. Note that the Durbin-Watson test for serial correlation does not work when the lagged dependent variable is used as a regressor. A generalized version, the Breusch-Godfrey test, does not work either with heteroskedastic errors. 
for $Q$. Given the very small measurement errors, it is likely that all measurement errors combined exhibit little auto-correlation, if any. ${ }^{18}$ This is plausible given that large swings in stock prices probably dominate other sources of measurement errors for $Q$. Based on (5), the one-period-ahead forecast errors including measurement errors for $Q$ can be expressed as:

$$
\begin{aligned}
\tilde{\xi} & =(Q+v)-\left\{X \gamma_{1 I V}+W \gamma_{2 I V}\right. \\
& +\left(Q^{-}+v^{-}\right) \alpha_{1 I V}+\left(X^{*}\left(Q^{-}+v^{-}\right)\right) \alpha_{2 I V}+\left(W^{*}\left(Q^{-}+v^{-}\right)\right) \alpha_{3 I V} \\
& \left.+Z \beta_{1 I V}+(X * Z) \beta_{2 I V}+\left(W^{*} Z\right) \beta_{3 I V}\right\} .
\end{aligned}
$$

Then, using $S$ to denote instrumental variables, we can write the estimation equation as the orthogonality condition with respect to this one-period-ahead forecast errors including measurement errors:

$$
E\left[S^{\prime} \tilde{\xi}\right]=0
$$

The usual requirement for instrumental variables, $S$, is that they need to be orthogonal to the original one-period-ahead forecast errors $\xi$. Here, they also need to be orthogonal to the measurement errors in order to remove the bias. We use twice-lagged $Q$ as the instrumental variable for lagged $Q$. This is a legitimate choice because the twice-lagged $Q$ is well correlated with the lagged $Q$, but orthogonal to the one-period-ahead forecast error in the current period and has a measurement error which is (empirically) orthogonal to the one associated with lagged $Q$. For the interaction terms, $\left(X^{*}\left(Q^{-}+v^{-}\right)\right)$and $\left(W^{*}\left(Q^{-}+v^{-}\right)\right)$, other instrumental variables are necessary for identification. Following Wooldridge (2002,

\footnotetext{
${ }^{18}$ If our test had indicated the presence of large measurement errors and the possibility of autocorrelation in the measurement errors themselves, the best estimation technique would have been the measurement-error-robust GMM estimation developed by Erickson and Whited (2000). But, this is not the case. Also, their estimation technique does not work well with fixed effects and heteroskedasticity (Almeida, Campello, and Galvao, 2011). Therefore we use a simpler IV estimation strategy described below.
} 
p.237), we construct them using the fitted value of lagged $Q$ (i.e., lagged $E[Q]$ in the limit), that is, $\left(X^{*} E\left[Q^{-}\right]\right)$and $\left(W^{*} E\left[Q^{-}\right]\right)$. These fitted values are obtained from OLS estimation. Otherwise, the procedure is a standard two-stage-least-squares estimation using lagged values as in many other studies (e.g., Almeida and Campello, 2010). ${ }^{19}$

Table 7 shows the results for the benchmark specification using instrumental variables. ${ }^{20}$ The results broadly replicate those of the OLS-fixed effects estimations. A notable difference is that the required rate of return is no longer affected by corporate governance but, instead, the curvature of financial frictions, $-b_{3}$, is now negatively and significantly correlated with corporate governance. This means that the marginal cost is lower for all firms and that the total cost is lower for most firms except for those with very small or very large financing needs. At the same time, and in line with the previous results, the large financing premium, represented by $-b_{2}$, is low in counties with good corporate governance and good general institutional quality. Creditor rights do not have any significant

\footnotetext{
${ }^{19}$ By construction, the equation is just-identified and the error term is not subject to serial correlation. Hence, the two stage least square procedure is both consistent and efficient. We do allow for potential heteroskedasticity (i.e., correlation in error terms) among firms in each country and each year, correcting for this by clustering at the country-year level. Theoretically, any $n$-times lagged $Q$ 's $(n>2)$ can be used as an instrumental variable to form an over-identified system (Arellano and Bond, 1991). As we have a not-so-small time dimension and a very large cross-section of firms, the computational burden forces us to use only the twice lagged $Q$ with the just-identified system.

${ }^{20}$ The instruments include approximation errors, because they are not perfectly correlated with the original variables (weak instruments). There are no well-established tests for the weak instrument problem in the case of heteroskedasticity but, following Baum, Schaffer, and Stillman (2007), we conduct two tests. The KleinbergenPaap $r k$ Wald test statistic is 5.14, which is not large enough to suggest that our instruments are not weak. However, the Anderson-Rubin $F$-statistic is 165 , rejecting the null hypothesis of under-identification, and confirming that the instruments are not weak. Note that the latter test is considered stronger than the former. In addition, in our case, approximation errors may exacerbate multicollinearity problems because the new error, the difference between the lagged $Q$ and the twice lagged $Q$, may be correlated with other regressors, $X$ (if $X$ is autocorrelated) and $W$. However, the empirical relevance of this problem is not well understood and this bias may be either small or large.
} 
effects; product market competition is associated with an increase in the required rate of return, possibly because it reduces monopolistic rents (which can make a firm less safe to lend to); and more developed financial markets raise the curvature of frictions (significant at the 10 percent significance level). These effects are, however, not robust to other specifications.

\section{Concluding Remarks}

We find that good corporate governance (shareholder rights) improves the economywide allocation of capital (i.e., small firms can raise funds on more equal footing). We also find in many tests that property rights or institutional quality have a similar effect on the ability of small firms to raise finance. In addition, corporate governance lowers the countryspecific required rate of return, benefiting all firms.

In contrast, creditor rights do not empirically play a major role in explaining movements in $Q$. One possible interpretation of this finding is that collateral constraints, which feature in many macroeconomic models, have been over-emphasized. Stated differently, good corporate governance (shareholder rights) is necessary to guarantee an efficient use of funds, regardless of whether the source of funding is debt (for which creditor rights may matter) or equity. Alternatively, the absence of evidence on the importance of creditor rights may be a feature of the sample we study (i.e., listed firms), which can relatively easily raise funds through both debt and equity finance. For these firms, the cost of external finance is perhaps determined by the cost of equity finance at the margin and so, 
naturally, shareholder rights matter more than creditor rights; we cannot rule out the possibility that collateral constraints may be important in other settings or for other firms. ${ }^{21}$ Our findings on the importance of shareholder rights and the relative lack of importance of creditor protection may also reflect differences in institutions and firm performance between the U.S. and other advanced countries like France, Germany, or Japan. U.S. firms are generally considered to offer better shareholder protection, whereas creditor rights are often considered weaker in the U.S. than in other developed economies. Our results are consistent with a conjecture that U.S. firms face fewer frictions and adjust investment faster than firms in other countries. ${ }^{22}$

In addition to presenting robust findings on the relation between investor protection, financial frictions, and investment, our approach offers certain methodological advantages. Rather than just documenting statistical associations, we identify specific structural parameters, based on a standard theory of investment. This approach allows us to disentangle the channels by which institutional factors affect financial frictions and, through them, investment. At the same time, our approach comes with caveats. We still use a somewhat reduced-form of financial frictions, because it is almost impossible to design a "horse race" between institutional variables from first principles (e.g., a moral hazard problem). This suggests an agenda for future research.

${ }^{21}$ See footnote 2.

${ }^{22}$ We also check if our results are largely driven by U.S. firms by rerunning the basic regressions after dropping U.S. firms from the sample. The benchmark results remain mostly unchanged (not tabulated). 


\section{REFERENCES}

Abel, Andrew B., and Olivier J. Blanchard (1986), "The Present Value of Profits and Cyclical Movements in Investment,” Econometrica, Vol. 54, No. 2, pp. 249-273.

Abel, Andrew B., Avinash Dixit, Janice C. Eberly and Robert Pindyck (1996), "Options, the Value of Capital, and Investment," Quarterly Journal of Economics, Vol. 111, No. 3, pp. 753-777.

and Janice C. Eberly (1994), “A Unified Model of Investment under

Uncertainty,” American Economic Review, Vol. 84, No. 5, pp. 1369-1384.

and (2008), "How $Q$ and Cash Flow Affect Investment

without Frictions: An Analytic Explanation," unpublished manuscript, Wharton School and Kellogg School.

Abiad, Abdul, Nienke Oomes, and Kenichi Ueda (2008), “The Quality Effect: Does Financial Liberalization Improve the Allocation of Capital?" Journal of Development Economics, Vol. 82, No. 2, pp. 270-282.

Acemoglu, Daron, and Fabrizio Zilibotti (1997), "Was Prometheus Unbound by Chance? Risk, Diversification, and Growth," Journal of Political Economy, Vol. 105(4), pp. 709-51.

Acharya, Viral V., Jean M. Imbs, and Jason Sturgess (2011), "Finance and Efficiency: Do Bank Branching Regulations Matter?” Review of Financial Studies, Vol. 15(1), pp. 135-172

Allen, Franklin, and Douglas Gale (2000), Comparing Financial Systems, Cambridge, MIT Press.

Almeida, Heitor, and Murillo Campello (2010), "Financing Frictions and the Substitution between Internal and External Funds," Journal of Financial and Quantitative Analysis, Vol. 45(03), pp. 589-622.

and Antonio F. Galvao Jr. (2010), "Measurement Errors in

Investment Equations," Review of Financial Studies, Vol. 23, pp. 3279-3328

, and Michael S. Weisbach (2011), "Corporate Financial and

Investment Policies when Future Financing is Not Frictionless," Journal of Corporate

Finance, Vol. 17(3), pp. 675-693.

Alvarez, Fernando, and Nancy L. Stokey (1998), "Dynamic Programming with Homogeneous Functions," Journal of Economic Theory, Vol.82, No.1, pp.167-89.

Arellano, Manuel, and Stephen Bond (1991), "Some Tests of Specification for Panel Data: Monte Carlo Evidence and an Application to Employment Equations," Review of Economic Studies, Vol. 58(2), pp. 277-97.

Banerjee, Abhijit V., and Andrew F. Newman (1993), "Occupational Choice and the Process 
of Development," Journal of Political Economy, Vol. 101, No. 2, pp. 274-298.

Barnet, Steven A., and Plutarchos Sakellaris (1999), "A New Look at Firm Market Value, Investment, and Adjustment Costs," The Review of Economics and Statistics, Vol. 81, No. 2, pp. 250-260.

Baum, Christopher F., Mark E. Schaffer, and Steven Stillman (2007), "Enhanced Routines for Instrumental Variables/Generalized Method of Moments Estimation and Testing," The Stata Journal, Vol. 7, pp. 465-506.

Beck, Thorsten, Ross Levine, and Norman Loayza (2000), "Finance and the Sources of Growth,” Journal of Financial Economics, Vol. 58, No. 1-2, pp. 261-300.

Bernanke, Ben, and Mark Gertler (1989), “Agency Costs, Net Worth, and Business Fluctuations,” American Economic Review, Vol. 79, No. 1, pp. 14-31.

Blanchard, Olivier, Changyong Rhee, and Lawrence Summers (1993), "The Stock Market, Profit, and Investment," The Quarterly Journal of Economics, Vol. 108, No. 1, pp. 115-136.

Bolton, Patrick, Hui Chen, and Neng Wang (2011), “A Unified Theory of Tobin's $Q$, Corporate Investment, Financing, and Risk Management," Journal of Finance, Vol. 66(5), pp. $1545-1578$.

Buera, Francisco., Joseph Kaboski, and Yongseok Shin (2011), "Finance and Development: A Tale of Two Sectors," American Economic Review, Vol. 101, No. 5, pp. 1964-2002.

Cagetti, Marco, and Mariacristina De Nardi (2006), "Entrepreneurship, Frictions, and Wealth,” Journal of Political Economy, Vol. 114, No. 5, pp. 835-870.

Chari, V. V., Patrick Kehoe, and Ellen McGrattan (2006), "Business Cycle Accounting," Econometrica, Vol. 75, Vol. 3, pp. 781-836.

Christiano, Laurence, Roberto Motto, and Massimo Rostagno (2010), "Financial Factors in Business Cycles," ECB Working Paper, No. 1192.

De Nicolo, Gianni, Luc Laeven, and Kenichi Ueda (2008), “Corporate Governance Quality: Trends and Real Effects," Journal of Financial Intermediation, Vol. 17, No. 2, pp. 198-228.

Demirguc-Kunt, Asli and Ross Levine (2001), Financial Structure and Economic Growth: A Cross-Country Comparison of Banks, Markets, and Development, Cambridge, MA, MIT Press.

Dittmar, Amy, Jan Mahrt-Smith, and Henri Servaes, 2003, "International Corporate Governance and Corporate Cash Holdings," Journal of Financial and Quantitative Analysis, Vol. 38, No. 1, pp.111-133.

Djankov, Simeon, Oliver Hart, Caralee McLiesh, and Andrei Shleifer (2008), "Debt Enforcement around the World," Journal of Political Economy, Vol. 116, No. 6, pp. 1105-49. 
, Caralee McLiesh, Andrei Shleifer (2007), "Private Credit in 129 Countries," Journal of Financial Economics, Vol. 84, No. 2, pp. 299-329.

, La Porta, Rafael, Florencio Lopez-de-Silanes, and Andrei Shleifer (2008),

"The Law and Economics of Self-Dealing," Journal of Financial Economics, Vol. 88, No. 3, pp. $430-465$.

Doidge, Craig G., Andrew Karolyi, and Rene M. Stulz (2007), "Why Do Countries Matter So Much for Corporate Governance?” Journal of Financial Economics, Vol. 86, No. 1, pp. 139.

Duffie, Darrell (2010), "Presidential Address: Asset Price Dynamics with Slow-Moving Capital,” Journal of Finance, Vol. 65, pp. 1237-1267.

Erickson, Timothy, and Toni M. Whited (2000), "Measurement Error and the Relationship between Investment and Q," Journal of Political Economy, Vol. 108, No. 5, pp. 1027-1057.

Fazzari, Steven M., Glenn R. Hubbard, and Bruce C. Petersen (1988), "Financing Constraints and Corporate Investment," Brookings Papers on Economic Activity, Vol. 19, pp. 141-206.

Gaudet, Gerard, Pierre Lasserre, and Ngo Van Long (1998), "Real Investment Decisions under Adjustment Cost and Asymmetric Information," Journal of Economic Dynamics and Control, Vol. 23, pp. 71-95.

Gertler, Mark and Nobuhiro Kiyotaki (2010), "Financial Intermediation in Credit Policy in Business Cycle Analysis," Handbook of Monetary Economics, manuscript.

Gomes, Joao F. (2001), “Financing Investment," American Economic Review, Vol. 91, No. 5, pp. 1263-1285.

Greenwood, Jeremy, and Boyan Jovanovic (1990), "Financial Development, Growth, and the Distribution of Income," Journal of Political Economy, Vol. 98, No. 5, pp. 1076-1107.

Greenwood, Jeremy, Juan M. Sanchez, and Cheng Wang (2010), "Financing Development: The Role of Information Costs," American Economic Review, Vol. 100(4), pp. 1875-91.

Greenwood, Jeremy, Juan M. Sanchez, and Cheng Wang (2013), "Quantifying the Impact of Financial Development on Economic Development," Review of Economic Dynamics, Vol. 16(1), pp. 194-215.

Greenwood, Robin (2005), “Aggregate Corporate Liquidity and Stock Returns," Harvard Business School Working Paper, No. 05-014.

Hayashi, Fumio (1982), "Tobin's Marginal q and Average q: A Neoclassical Interpretation," Econometrica, Vol. 50, No. 1, pp. 213-224.

Hennessy, Christopher A., Amnon Levy, and Toni M. Whited (2007), "Testing $Q$ Theory with Financing Frictions," Journal of Financial Economics, Vol. 83, No. 3, pp. 691-717. 
Hsieh, Chang-Tai, and Peter Klenow (2009), "Misallocation and Manufacturing TFP in China and India,” Quarterly Journal of Economics, Vol. 124, No. 4, pp. 1403-1448.

Hsieh, Chang-Tai, and Peter Klenow (2012), "The Life Cycle of Plants in India and Mexico," NBEER Working Paper, No.18133.

International Monetary Fund (2009), International Financial Statistics, Washington, D.C.

Karaivanov, Alexander, Jesus Saurina, Robert M. Townsend, and Sonia Ruano (2010), "No Bank, One Bank, Several Banks: Does It Matter for Investment?" manuscript.

Kaufmann, Daniel, Aart Kraay, and Massimo Mastruzzi (2004), "Governance Matters III: Updated Governance Indicators for 1996, 1998, 2000, and 2002," World Bank Economic Review, Vol. 18, No. 2, pp. 253-287.

Khan, Aubhik, and Julia K. Thomas (2008), "Idiosyncratic Shocks and the Role of Nonconvexities in Plant and Aggregate Investment Dynamics," Econometrica, Vol. 76, No. 2, pp. 395-436.

Kiyotaki, Nobuhiro, and John Moore (1997), "Credit Cycles," Journal of Political Economy, Vol. 105, No 2, pp. 211-248.

Klapper, Leora, and Inessa Love (2011), "The Impact of the Financial Crisis on New Firm Registration," Economic Letters, Vol. 113, No. 1, pp. 1-4.

Klenow, Peter J., and Andrés Rodríguez-Clare (1997), "The Neoclassical Revival in Growth Economics: Has It Gone Too Far?" in B. Bernanke and J. Rotemberg, eds., NBER Macroeconomics Annual 1997. Cambridge, MA: MIT Press, pp. 73-102.

La Porta, Rafael, Florencio Lopez-de-Silanes, and Andrei Shleifer (2008), "The Economic Consequences of Legal Origins," Journal of Economic Literature, Vol. 46, No. 2, pp. 285332.

$\overline{\text { Finance," Journal of Political Economy, Vol. 106, No. 6, pp. 1113-1155. }}$

Levine, Ross (2005), "Finance and Growth: Theory and Evidence." in Philippe Aghion and Steven Durlauf, eds. Handbook of Economic Growth. The Netherlands: Elsevier Science.

Lorenzoni, Guido, and Karl Walentin (2007), "Financial Frictions, Investment, and Tobin's q," NBER Working Paper, No. 13092.

McLean, David R., Tianyu Zhang, and Mengxin Zhao (2011), "Why Does the Law Matter? Investor Protection and its Effects on Investment, Finance, and Growth," Journal of Finance, Vol. 67(1), pp. 313-350.

Morck, Randall, Daniel Wolfenzon, and Bernard Yeung (2005), "Corporate Governance, Economic Entrenchment, and Growth,” Journal of Economic Literature, Vol. 43, No. 3, pp. 655-720. 
Mussa, Michael (1977), "External and Internal Adjustment Costs and the Theory of Aggregate and Firm Investment," Economica, Vol. 44, No. 174, pp. 163-178.

Myers, Stewart, and Nicholas Majluf (1984), "Corporate Financing and Investment Decisions When Firms Have Information That Investors Do Not Have," Journal of Financial Economics, Vol. 13, pp. 187-221.

Parente, Stephen, and Edward Prescott (2000), Barriers to Riches, MIT Press, Cambridge.

Paulson, Anna L., and Robert M. Townsend (2008), "Entrepreneurial Heterogeneity: Insights from the Thai Financial Crisis," unpublished manuscript, FRB Chicago and MIT.

Philippon, Thomas (2009), “The Bond Market's Q," Quarterly Journal of Economics, Vol. 124, No. 3, pp. 1011-1056.

Rajan, Raghuram G. and Luigi Zingales (1998), "Financial Dependence and Growth," American Economic Review, Vol. 88, No. 3, pp. 559-586.

Tobin, James (1969), “A General Equilibrium Approach to Monetary Theory,” Journal of Money Credit and Banking, Vol. 1, No. 1, pp 15-29.

Townsend, Robert M. (1979), "Optimal Contracts and Competitive Markets with Costly State Verification,” Journal of Economic Theory, Vol. 21, No. 2, pp. 265-293.

Townsend, Robert M. and Kenichi Ueda (2006), "Financial Deepening, Inequality, and Growth: A Model-Based Quantitative Evaluation," Review of Economic Studies, Vol.73, No. 1, pp. 251-293.

Townsend, Robert M. and Kenichi Ueda (2010), "Welfare Gains from Financial

Liberalization,” International Economic Review, Vol. 51, No. 3, pp. 553-597.

Wooldridge, Jeffrey M. (2002), Econometric Analysis of Cross Section and Panel Data, The MIT Press, Cambridge, MA.

World Economic Forum (2007), The Global Competitiveness Report 2006-2007, Oxford University Press, New York.

World Bank (2008a), Doing Business, Washington, D.C. (2008b), World Development Indicators, Washington, D.C.

World Values Survey 1990-1993, available at www.worldvaluessurvey.org

Wurgler, Jeffrey (2000), "Financial Markets and the Allocation of Capital," Journal of Financial Economics, Vol. 58, No. 1-2, pp. 187-214. 
Figure 1. Financial Transaction Costs as a Function of Capital K given External Finance $B$ (Size Effect/Small Firm Premium)

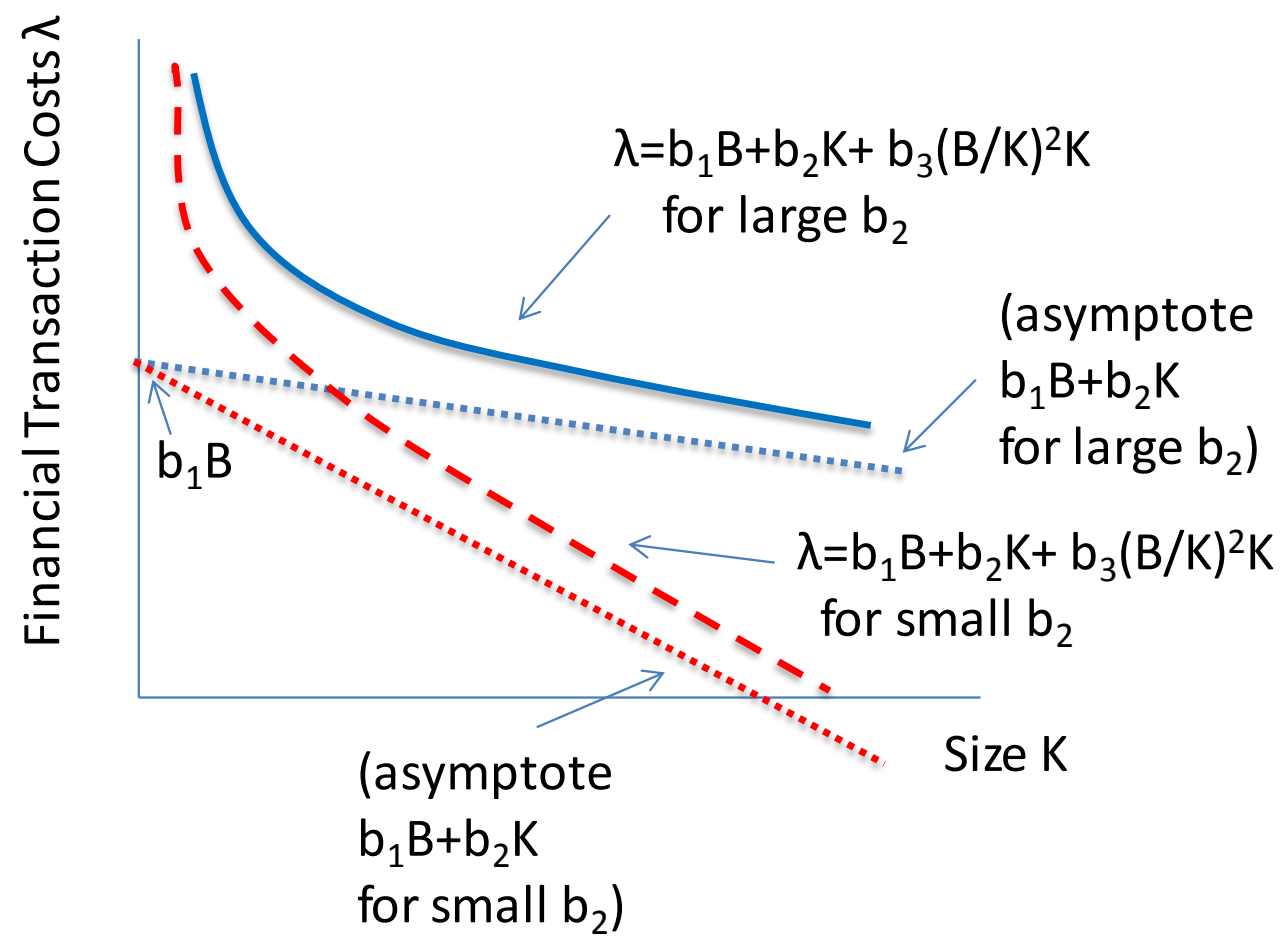

Figure 2. Financial Transaction Cost Curve Based on Regression Results (Average (solid) and One-Standard-Deviation Better (dashed) and Worse (dotted) Institutions)

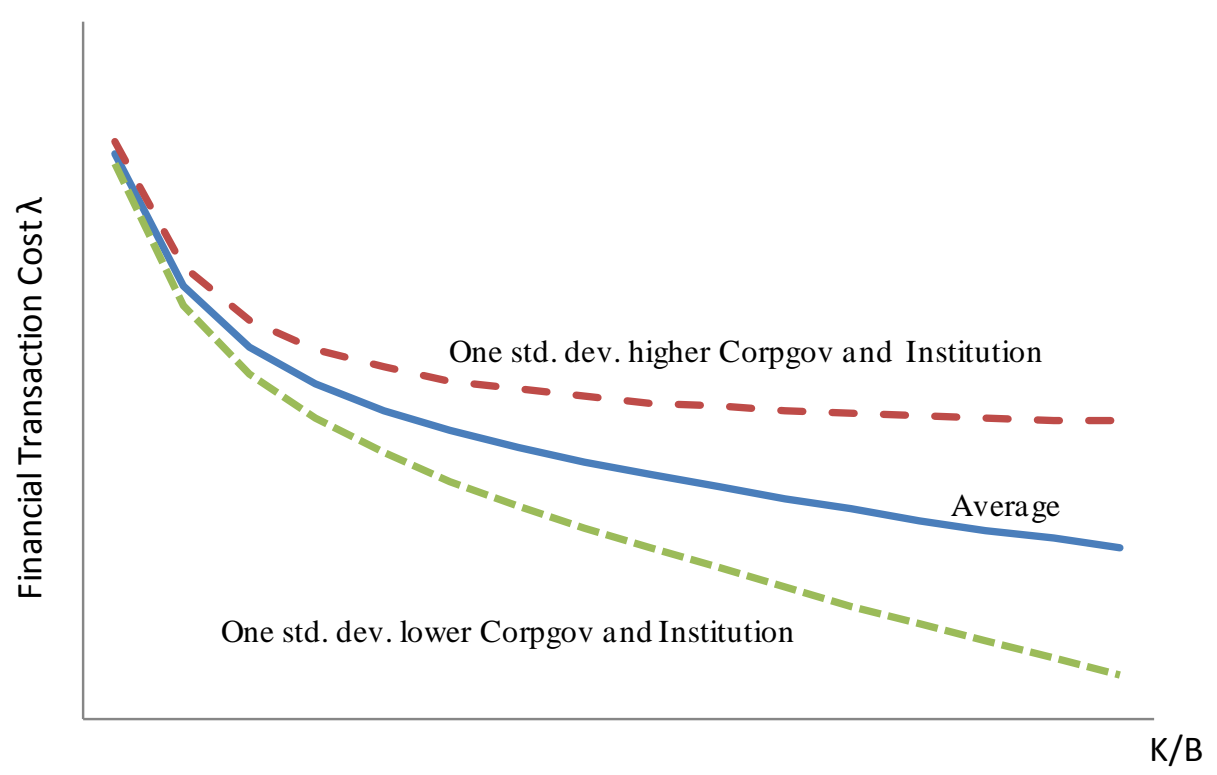


Figure 3. Overall Effect Based on Regression Results

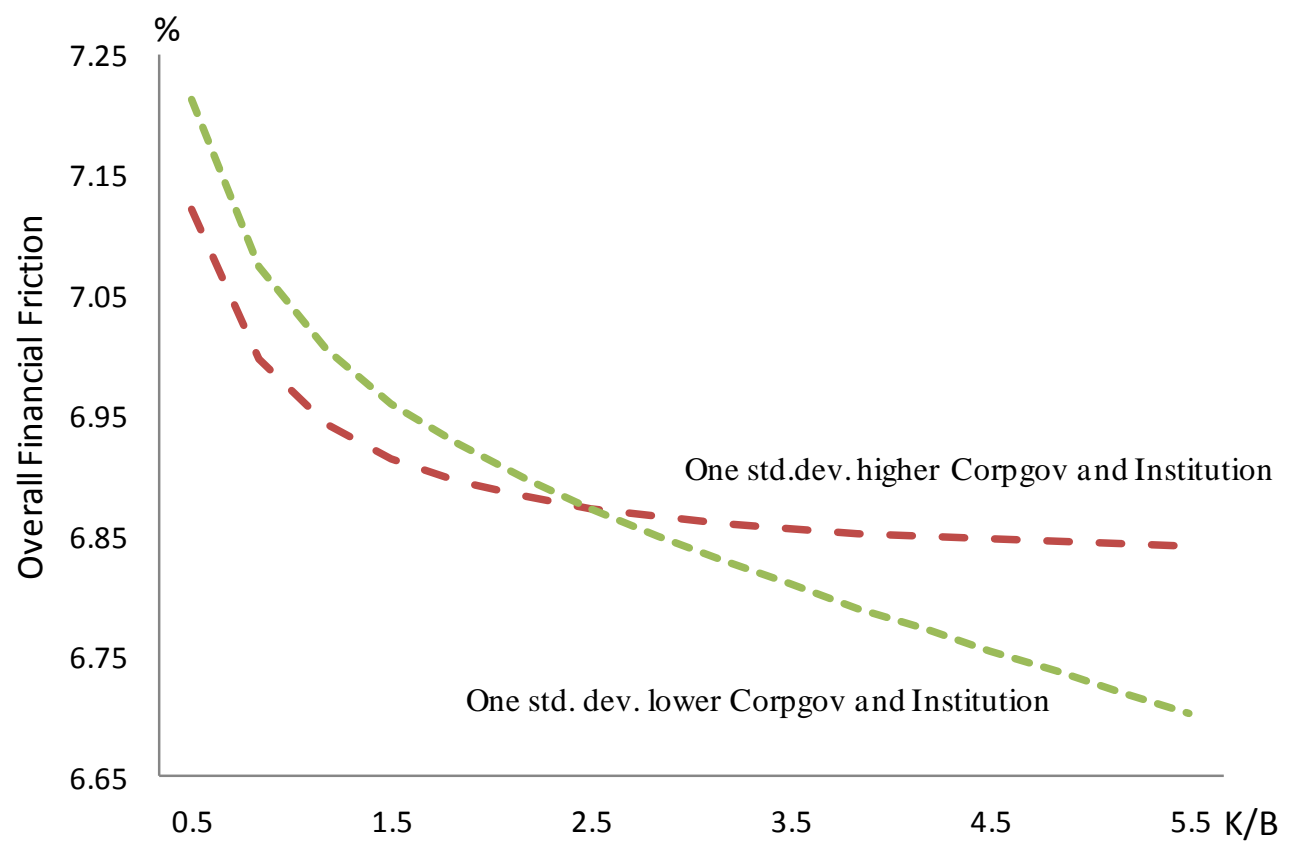


Table 1a. Variables: Definition, Sources and Descriptive Statistics

\begin{tabular}{|c|c|c|c|c|c|c|c|c|}
\hline Variable & Definition/Source & Mean & Std.Dev & $25 \%$ & Median & $75 \%$ & Obs & Obs $>0$ \\
\hline \multicolumn{9}{|c|}{ Worldscope Data } \\
\hline Q & Tobin's Q & 3.3 & 157.2 & 1.0 & 1.3 & 1.9 & 290365 & \\
\hline Age & Company Age & 33.4 & 35.3 & 9.0 & 23.0 & 49.0 & 270716 & \\
\hline \multirow{2}{*}{ Marginal Profit } & Before-Tax Income & -0.2 & 80.8 & -0.1 & 0.1 & 0.4 & 267702 & \\
\hline & After-Tax Income & -0.1 & 57.9 & -0.1 & 0.1 & 0.4 & 266740 & \\
\hline \multirow[b]{2}{*}{ Investment } & capital expenditure over total assets & 0.1 & 0.5 & 0.0 & 0.0 & 0.1 & 288089 & 262190 \\
\hline & $\begin{array}{l}\text { capital expenditure plus change in cash over total } \\
\text { assets }\end{array}$ & 0.0 & 4.7 & 0.0 & 0.1 & 0.1 & 251275 & 198731 \\
\hline \multirow{2}{*}{ External Finance } & $\begin{array}{l}\text { capital expenditure plus change in cash correcting for } \\
\text { invetories and trade credits over total assets }\end{array}$ & 0.3 & 21.7 & 0.0 & 0.0 & 0.1 & 229828 & 99970 \\
\hline & $\begin{array}{l}\text { change in total debt plus new cash from equity sales } \\
\text { over total assets }\end{array}$ & 0.1 & 15.7 & 0.0 & 0.0 & 0.1 & 266528 & 155578 \\
\hline \multicolumn{9}{|c|}{ Country Level Variables } \\
\hline Interest & Interest Rate/IFS & 6.9 & 9.6 & 2.4 & 4.0 & 7.4 & 816 & \\
\hline Inflation & Inflation Rate/IFS & 17.2 & 116.3 & 1.8 & 3.2 & 8.3 & 766 & \\
\hline \multirow{3}{*}{ Corporate Gov } & Antidirector Rights Index/ La Porta, et al. (1998) & 3.1 & 1.3 & 2.0 & 3.0 & 4.0 & 42 & \\
\hline & Self Dealing Index/ Djankov, et al. (2008) & 0.5 & 0.2 & 0.3 & 0.5 & 0.7 & 48 & \\
\hline & $\begin{array}{l}\text { Corporate Governance Quality Index/ De Nicolo, et al. } \\
(2008)\end{array}$ & 0.6 & 0.1 & 0.6 & 0.6 & 0.6 & 45 & \\
\hline \multirow{3}{*}{ Creditors' Right } & Strength of Legal Right Index/Doing Business (2007) & 6.1 & 2.3 & 4.0 & 7.0 & 8.0 & 48 & \\
\hline & Creditor Rights / Djankov, et al. (2008) & 1.9 & 1.1 & 1.0 & 2.0 & 3.0 & 45 & \\
\hline & \begin{tabular}{|l} 
Efficiency of Bankruptcy Law/ Global Competitiveness \\
Report (2004)
\end{tabular} & 5.2 & 1.0 & 4.3 & 5.2 & 6.0 & 48 & \\
\hline \multirow{3}{*}{ Institional Quality } & $\begin{array}{l}\text { Property Rights/ Heritage Foundation and Wall Street } \\
\text { Journal Index of Economic Freedom (1997) }\end{array}$ & 4.3 & 0.8 & 4.0 & 4.5 & 5.0 & 40 & \\
\hline & Rule of Law in 2000/ Kaufman, et al. (2004) & 1.0 & 1.0 & 0.2 & 1.2 & 2.0 & 42 & \\
\hline & Trust in People/ World Values Survey 1990-1993 & 0.4 & 0.2 & 0.3 & 0.4 & 0.5 & 26 & \\
\hline \multirow{3}{*}{$\begin{array}{l}\text { Product Market } \\
\text { Competition }\end{array}$} & $\begin{array}{l}\text { Barriers to Trade in 2007/World Economic Forum Global } \\
\text { Competitiveness Report (2007) }\end{array}$ & 5.0 & 0.8 & 4.2 & 5.1 & 5.5 & 48 & \\
\hline & $\begin{array}{l}\text { Business Entry Rate in } 2005 \text { (New Registrations as \% of } \\
\text { Total)/WDI }\end{array}$ & 9.9 & 3.6 & 6.7 & 9.9 & 12.7 & 38 & \\
\hline & $\begin{array}{l}\text { Cost of Starting a Business in 2007(\% of income per } \\
\text { capita)/Doing Business }\end{array}$ & 12.9 & 17.0 & 2.4 & 7.7 & 19.8 & 48 & \\
\hline \multirow{3}{*}{ Financial Dev } & Market Capitalization to GDP in 2006/ WDI & 102.5 & 83.0 & 43.6 & 83.7 & 126.7 & 47 & \\
\hline & $\begin{array}{l}\text { Sum of stock market capitalization and private bond } \\
\text { market capitalization and bank credit over GDP in 2007/ } \\
\text { IFS }\end{array}$ & 2.2 & 1.3 & 1.0 & 2.0 & 3.1 & 41 & \\
\hline & \begin{tabular}{|l|} 
Foreign Ownership Restrictions/ World Economic \\
Forum Global Competitiveness Report (2007)
\end{tabular} & 5.4 & 0.7 & 5.0 & 5.5 & 6.0 & 48 & \\
\hline \multirow{3}{*}{ Macro Volatility } & Standard Deviation of GDP growth/ WDI & 2.8 & 1.6 & 1.4 & 2.1 & 3.7 & 47 & \\
\hline & Coefficient of Variation of Exchange Rate/WEO & 0.4 & 0.6 & 0.1 & 0.2 & 0.4 & 48 & \\
\hline & Standard Deviation of Inflation/ WDI & 31.0 & 117.7 & 1.3 & 3.0 & 9.2 & 47 & \\
\hline
\end{tabular}




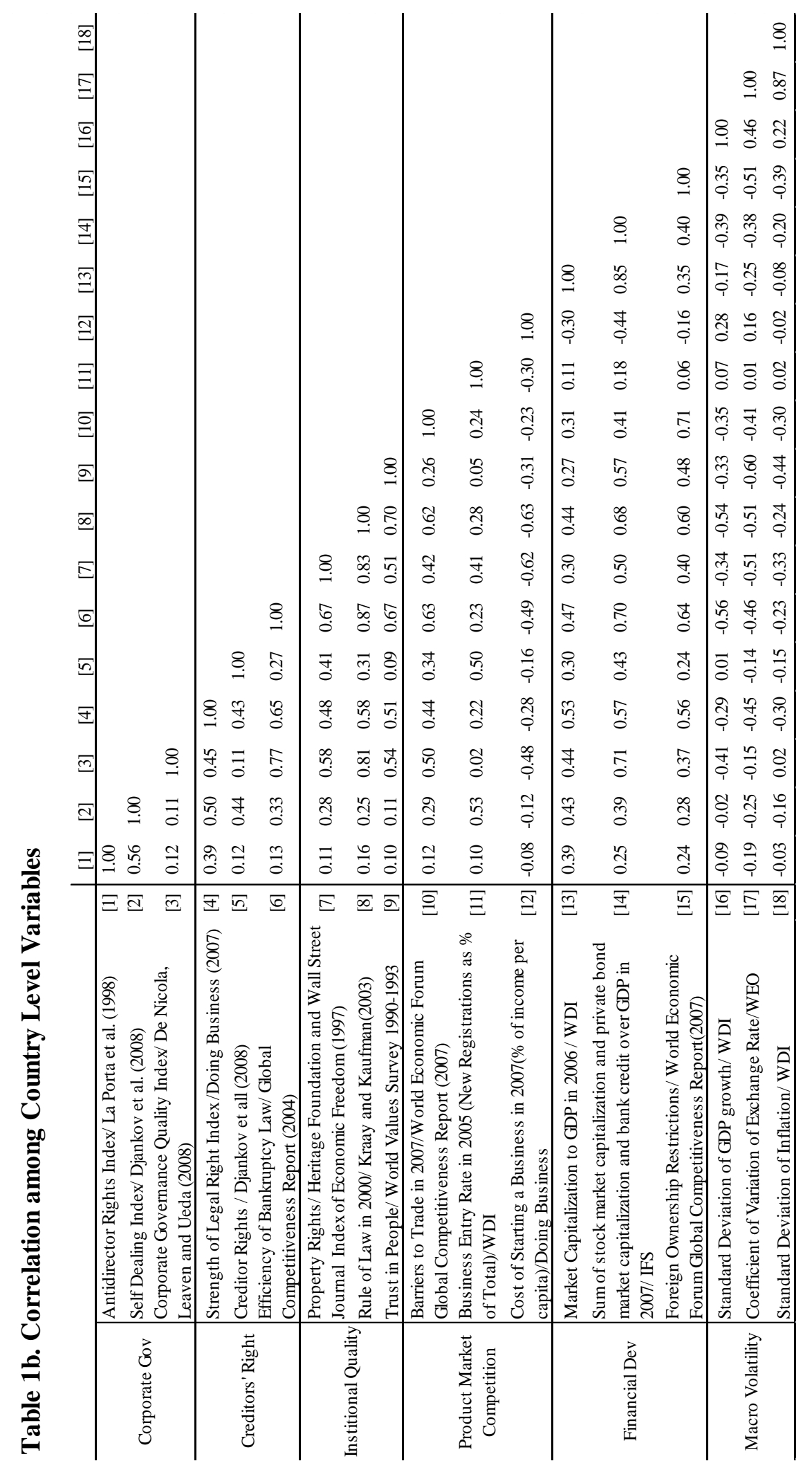




\section{Table 2. Benchmark Regressions}

\begin{tabular}{|c|c|c|c|c|c|c|}
\hline & $\begin{array}{c}\mathbf{a} \\
\text { Required Return } \\
{[1]} \\
\end{array}$ & $\begin{array}{c}\text {-b1 } \\
\text { (-) Fin. Friction } \\
\text { Coeff. Ext. Fin. } \\
{[2]} \\
\end{array}$ & $\begin{array}{c}\text { b2 } \\
\text { Fin. Friction } \\
\text { Coeff. Capital } \\
\text { [3] } \\
\end{array}$ & $\begin{array}{c}-\mathbf{b 3} \\
\text { (-) Fin. Friction } \\
\text { Curvature } \\
{[4]} \\
\end{array}$ & $\begin{array}{c}\text { c2 } \\
\text { Inv. Adj. Cost } \\
\text { Coeff. Capital } \\
{[5]} \\
\end{array}$ & $\begin{array}{c}-\mathbf{c 3} \\
\text { (-) Inv. Adj. Cost } \\
\text { Curvature } \\
{[6]} \\
\end{array}$ \\
\hline \multicolumn{7}{|l|}{ Institutional Factors } \\
\hline \multirow[t]{2}{*}{ Corporate Governance } & -0.0433 & -0.0028 & 0.0200 & 0.0230 & & \\
\hline & {$[-2.403]^{* *}$} & {$[-1.778]^{*}$} & {$[2.639]^{* * *}$} & [1.167] & & \\
\hline \multirow[t]{2}{*}{ Creditor Rights } & -0.0099 & -0.0042 & -0.0102 & 0.0399 & & \\
\hline & {$[-0.454]$} & {$[-1.119]$} & {$[-1.673]^{*}$} & [1.148] & & \\
\hline \multirow[t]{2}{*}{ Institution } & -0.0007 & 0.0091 & 0.0639 & -0.2282 & & \\
\hline & {$[-0.016]$} & {$[0.734]$} & {$[3.683]^{* * *}$} & {$[-1.750]^{*}$} & & \\
\hline Product Market & 0.0772 & 0.0003 & -0.0071 & -0.0950 & & \\
\hline Competition & {$[1.864]^{*}$} & [0.045] & {$[-0.423]$} & {$[-0.858]$} & & \\
\hline \multirow[t]{2}{*}{ Financial Markets } & 0.0001 & 0.0000 & 0.0001 & -0.0004 & & \\
\hline & {$[0.357]$} & {$[-0.167]$} & {$[0.414]$} & {$[-0.508]$} & & \\
\hline \multicolumn{7}{|l|}{ Real Factors } \\
\hline \multirow[t]{2}{*}{ Firm Age } & 0.0026 & 0.0001 & -0.0003 & 0.0000 & 0.0034 & 0.0140 \\
\hline & {$[5.296]^{* * *}$} & {$[1.501]$} & {$[-1.243]$} & {$[-0.035]$} & [0.987] & [1.146] \\
\hline \multirow[t]{2}{*}{ Risk Free Rate } & 0.0036 & 0.0002 & 0.0038 & -0.0234 & 0.0170 & -0.0656 \\
\hline & {$[0.346]$} & {$[0.102]$} & {$[1.521]$} & {$[-0.823]$} & [1.370] & {$[-0.729]$} \\
\hline \multirow[t]{2}{*}{ Inflation } & -0.0075 & 0.0026 & -0.0003 & -0.0210 & -0.0224 & 0.1453 \\
\hline & {$[-0.706]$} & {$[0.697]$} & {$[-0.101]$} & {$[-0.598]$} & {$[-1.613]$} & [1.308] \\
\hline \multirow[t]{2}{*}{ Macro Volatility } & -0.0381 & -0.0030 & -0.0028 & 0.0025 & 0.1359 & 0.0068 \\
\hline & {$[-1.352]$} & {$[-1.120]$} & {$[-0.358]$} & {$[0.093]$} & {$[1.440]$} & {$[0.023]$} \\
\hline Observations & & & & & & 74272 \\
\hline R-squared & & & & & & 0.496 \\
\hline
\end{tabular}

Note: The dependent variable is Tobin's Q. This table shows key coefficient estimates on theoretically derived interaction terms in equation (6) and organized in the following manner. Column 1 presents the effects of various institutional and real factors on the common required rate of return. Column 2 presents the effects on the marginal financial transaction costs. Column 3 presents the effects on the sensitivity of the financial transaction costs to firm. Column 4 presents the effects on the curvature of the financial transaction cost function. Column 5 presents the effects on the sensitivity of the technological (non-financial) investment adjustment cost function to firm size, and column 6 presents the effects on the curvature of the investment adjustment cost function. Country and year fixed effects are included but not reported. T-statistics are presented in parenthesis based on robust standard errors clustered at the country-year level: * denotes significant at 10 percent, ** at 5 percent, and *** at 1 percent. 
Table 3a. Regressions Using Before-Tax Income

Required Return

[1]

Institutional Factors

Corporate Governance

$-0.0443$

$[-2.461]^{* *}$

$-0.0039$

$[-2.576]^{* *}$

(-) Fin. Friction

Coeff. Ext. Fin.

[2]

Creditor Rights

$-0.0098$

[-0.447]

$-0.0052$

[-0.119]

0.0015

[0.435]

$[2.613]^{* * *}$

Institution

Product Market

Competition

Financial Markets

0.0761

[1.825]*

0.0001

0.0000

0.0018

[0.203]

$-0.0074$

[-0.460]

[0.356]

[-0.981]
0.0204

0.0284

[1.612]

$[3.588]^{* * *}$

$-0.1433$

$-0.0091$

0.0158

[-1.406]

[0.355]

$-b 3$

(-) Fin. Friction

Curvature

[4]

[-0.706]

$-0.0986$

$[-0.642]$

$[-0.481]$

$-0.0008$

[-1.007]

Observations

74249

R-squared

0.509

Note: The dependent variable is Tobin's Q. This table shows key coefficient estimates on theoretically derived interaction terms in equation (6) and organized in the same manner as in Table 2. The change in income definition should affect column 2 and 4 directly and other columns indirectly. Real factors as well as country and year fixed effects are included but not reported. T-statistics are presented in parenthesis based on robust standard errors clustered at the country-year level: * denotes significant at 10 percent, ** at 5 percent, and *** at 1 percent. 


\section{Table 3b. Regressions Using a Broad Concept of Investment (incl. Security Investment)}

Required Return

\section{Institutional Factors}

Corporate Governance

Creditor Rights

Institution

Product Market

Competition

Financial Markets a

[1]

-b1

(-) Fin. Friction

Coeff. Ext. Fin.

[2]

$-0.0456$

$[-2.519]^{* *}$

$-0.0105$

[-0.482]

$-0.0069$

[-0.158]

0.0767

[1.867]*

0.0001

[0.392]

$[-1.869]^{*}$

$-0.0039$

[-1.127]

0.0076

[0.663]

$-0.0006$

[-0.094]

0.0000

[-0.131]
Fin. Friction

Coeff. Capital

$[2.837]^{* * * *}$

[-1.644]

[3.681]*** b2

[3]

0.0211

$-0.0100$

0.0641

-0.2125
$[-1.800]^{*}$

-0.2125
$[-1.800]^{*}$

$-b 3$

(-) Fin. Friction

Curvature

[4]

0.0259

[1.310]

0.0371

[1.161]

$-0.0792$

[-0.808]

[-0.397]

0.0000

$-0.0004$

[0.135]

Observations

74272

R-squared

0.503

Note: The dependent variable is Tobin's Q. This table shows key coefficient estimates on theoretically derived interaction terms in equation (6) and organized in the same manner as in Table 2 . The change in income definition should affect column 4 directly and other columns indirectly. Real factors as well as country and year fixed effects are included but not reported. T-statistics are presented in parenthesis based on robust standard errors clustered at the country-year level: * denotes significant at 10 percent, ** at 5 percent, and *** at 1 percent. 
Table 3c. Regressions Using a Narrow Concept of External Finance (excl. Trade Credit)

a

Required Return -b1

(-) Fin. Friction

Coeff. Ext. Fin. b2

Fin. Friction

Coeff. Capital $-b 3$

(-) Fin. Friction

Curvature

[4]

\begin{tabular}{lcccc}
\hline Institutional Factors & & & & \\
Corporate Governance & -0.0132 & 0.0002 & 0.0102 & 0.0109 \\
& {$[-0.586]$} & {$[0.109]$} & {$[1.650]^{*}$} & {$[0.568]$} \\
Creditor Rights & -0.0324 & 0.0013 & -0.0003 & -0.0101 \\
& {$[-0.847]$} & {$[1.485]$} & {$[-0.033]$} & {$[-0.938]$} \\
Institution & & & & 0.0000 \\
& 0.0001 & 0.0014 & 0.0139 & {$[]$.} \\
Product Market & {$[0.002]$} & {$[0.574]$} & {$[0.743]$} & 0.0142 \\
Competition & & & & {$[0.478]$} \\
& 0.0253 & 0.0006 & -0.0159 & \\
Financial Markets & {$[0.199]$} & {$[0.350]$} & {$[-0.597]$} & 0.0002 \\
& & & & {$[0.544]$} \\
\hline R-squared & 0.0008 & -0.0000 & -0.0001 & 81562 \\
\hline & {$[2.243]^{* *}$} & {$[-0.664]$} & {$[-0.282]$} & 0.294 \\
\hline
\end{tabular}

Note: The dependent variable is Tobin's Q. This table shows key coefficient estimates on theoretically derived interaction terms in equation (6) and organized in the same manner as in Table 2 . The change in income definition should affect column 4 directly and other columns indirectly. Real factors as well as country and year fixed effects are included but not reported. T-statistics are presented in parenthesis based on robust standard errors clustered at the country-year level: * denotes significant at 10 percent, $* *$ at 5 percent, and $* * *$ at 1 percent. 
Table 4. One-by-One Regressions

a

Required Return

[1]

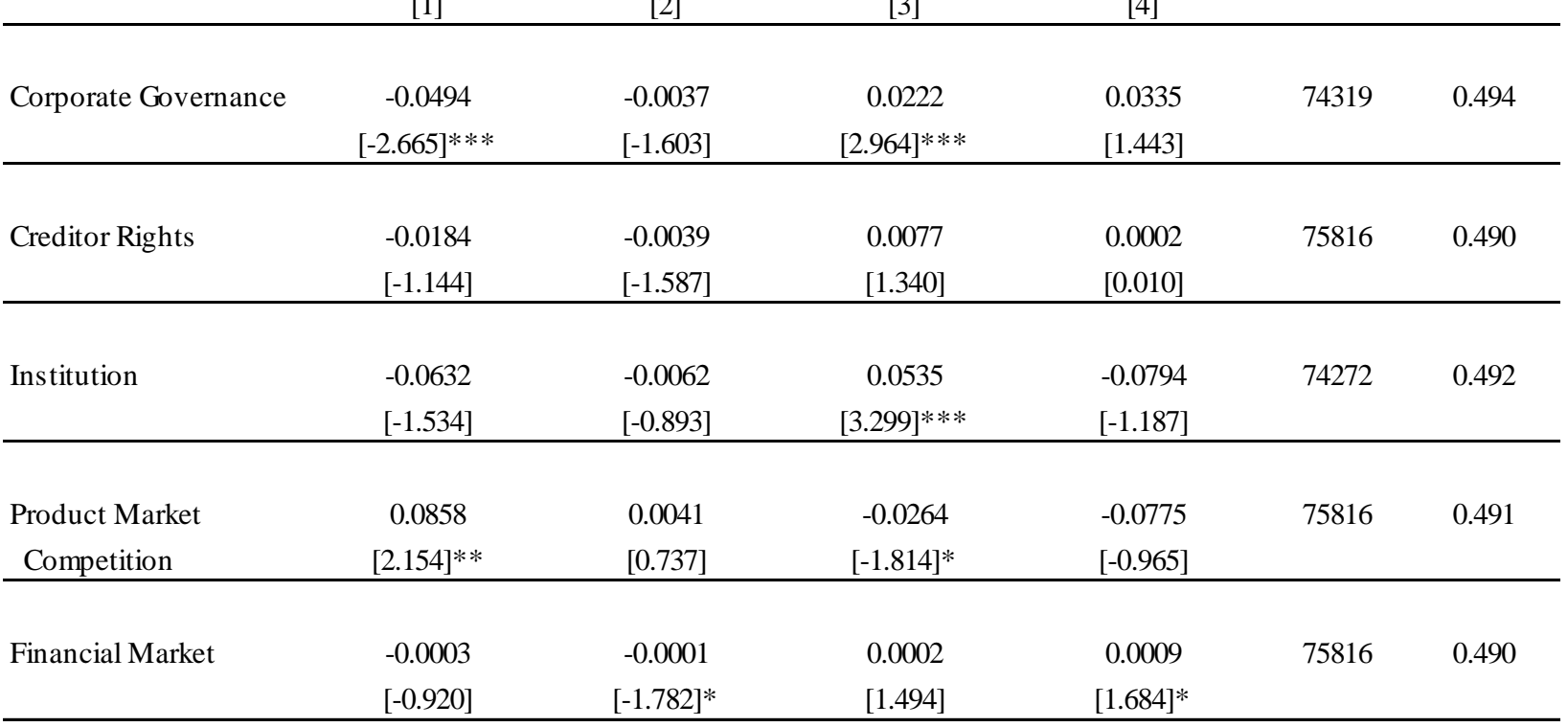

Note: The dependent variable is Tobin's Q. This table shows key coefficient estimates on theoretically derived interaction terms in equation (6). Columns are organized in the same manner as in Table 2. However, each row shows results from different regressions: each regression include interaction terms with one institutional variable only. Real factors as well as country and year fixed effects are included but not reported. T-statistics are presented in parenthesis based on robust standard errors clustered at the country-year level: * denotes significant at 10 percent, $* *$ at 5 percent, and $* * *$ at 1 percent.

$-b 3$

(-) Fin. Friction Fin. Friction

Coeff. Ext. Fin. Coeff. Capital

(-) Fin. Friction

Curvature

Obs R-Squared

- 
Table 5. Alternative Definitions of Institutional Factors

\begin{tabular}{|c|c|c|c|c|c|c|}
\hline & $\begin{array}{c}\text { a } \\
\text { Required Return } \\
{[1]} \\
\end{array}$ & $\begin{array}{c}\quad \mathbf{- b 1} \\
\text { (-) Fin. Friction } \\
\text { Coeff. Ext. Fin. } \\
\text { [2] } \\
\end{array}$ & $\begin{array}{c}\text { b2 } \\
\text { Fin. Friction } \\
\text { Coeff. Capital } \\
\text { [3] } \\
\end{array}$ & $\begin{array}{c}-\mathbf{b 3} \\
\text { (-) Fin. Friction } \\
\text { Curvature } \\
{[4]} \\
\end{array}$ & Obs & R-Squared \\
\hline \multicolumn{7}{|l|}{ Corporate Governance } \\
\hline \multirow[t]{2}{*}{ Self-Dealing Index } & -0.1745 & -0.0187 & 0.1030 & -0.0789 & 74272 & 0.4950 \\
\hline & {$[-1.267]$} & {$[-1.060]$} & {$[1.828]^{*}$} & {$[-0.367]$} & & \\
\hline \multirow[t]{2}{*}{ CGQ-Index } & -0.7344 & -0.3374 & 1.2952 & 2.9030 & 73619 & 0.4990 \\
\hline & {$[-0.756]$} & {$[-2.152]^{* *}$} & {$[2.930]^{* * *}$} & {$[1.372]$} & & \\
\hline \multicolumn{7}{|l|}{ Creditor Rights } \\
\hline \multirow[t]{2}{*}{ Narrower Definition } & -0.0083 & 0.0095 & -0.0326 & -0.0580 & 73887 & 0.4950 \\
\hline & {$[-0.272]$} & {$[1.454]$} & {$[-2.752]^{* * *}$} & {$[-0.647]$} & & \\
\hline \multirow[t]{2}{*}{ Bankruptcy Efficiency } & 0.0195 & -0.0058 & 0.0385 & -0.1338 & 74272 & 0.4960 \\
\hline & {$[0.328]$} & {$[-0.599]$} & {$[1.565]$} & {$[-1.125]$} & & \\
\hline \multicolumn{7}{|l|}{ Institution } \\
\hline \multirow[t]{2}{*}{ Rule of Law } & 0.0178 & 0.0189 & 0.0566 & -0.3387 & 74319 & 0.4960 \\
\hline & {$[0.333]$} & {$[1.368]$} & {$[2.679]^{* * *}$} & {$[-2.479]^{* *}$} & & \\
\hline \multirow[t]{2}{*}{ People's Trust } & 0.3880 & 0.0377 & 0.2505 & -0.5678 & 67431 & 0.5070 \\
\hline & {$[1.748]^{*}$} & {$[1.381]$} & {$[2.945]^{* * *}$} & {$[-2.025]^{* *}$} & & \\
\hline \multicolumn{7}{|l|}{ Product Market Competition } \\
\hline \multirow[t]{2}{*}{ New Firm Entry } & -0.0013 & -0.0024 & 0.0063 & 0.0212 & 68040 & 0.4970 \\
\hline & {$[-0.190]$} & {$[-1.546]$} & {$[1.864]^{*}$} & {$[0.934]$} & & \\
\hline \multirow[t]{2}{*}{ Business Start-Up Cost } & 0.0006 & -0.0003 & -0.0005 & 0.0129 & 74272 & 0.4950 \\
\hline & {$[0.296]$} & {$[-1.522]$} & {$[-0.741]$} & {$[3.127]^{* * *}$} & & \\
\hline \multicolumn{7}{|l|}{ Financial Market } \\
\hline \multirow[t]{2}{*}{ Private Credit/GDP } & 0.0360 & 0.0036 & -0.0023 & -0.0168 & 74272 & 0.4960 \\
\hline & {$[0.680]$} & {$[0.423]$} & {$[-0.137]$} & {$[-0.239]$} & & \\
\hline Absence of Foreign & 0.0238 & 0.0012 & 0.0097 & 0.0170 & 73325 & 0.4960 \\
\hline Ownership Restrictions & {$[0.899]$} & {$[0.312]$} & {$[0.901]$} & {$[0.436]$} & & \\
\hline
\end{tabular}

Note: The dependent variable is Tobin's Q. This table shows key coefficient estimates on theoretically derived interaction terms in equation (6) and organized in the same manner as in Table 2. Each row represents different regressions. Although all five institutional variables are included in each regression, each row shows only the coefficients for interaction terms that use the alternate institutional variable. Real factors as well as country and year fixed effects are included but not reported. T-statistics are presented in parenthesis based on robust standard errors clustered at the country-year level: * denotes significant at 10 percent, ** at 5 percent, and *** at 1 percent. 


\section{Table 6. Including Institutional Effects in Real Investment Adjustment}

\begin{tabular}{|c|c|c|c|c|c|c|}
\hline & $\begin{array}{c}\mathbf{a} \\
\text { Required Return } \\
{[1]} \\
\end{array}$ & $\begin{array}{c}\text {-b1 } \\
\text { (-) Fin. Friction } \\
\text { Coeff. Ext. Fin. } \\
\text { [2] }\end{array}$ & $\begin{array}{c}\text { b2 } \\
\text { Fin. Friction } \\
\text { Coeff. Capital } \\
{[3]} \\
\end{array}$ & $\begin{array}{c}-\mathbf{b 3} \\
\text { (-) Fin. Friction } \\
\text { Curvature } \\
{[4]} \\
\end{array}$ & $\begin{array}{c}\mathbf{c 2} \\
\text { Inv. Adj. Cost } \\
\text { Coeff. Capital } \\
{[5]} \\
\end{array}$ & $\begin{array}{c}\mathbf{- c 3} \\
\text { (-) Inv. Adj. Cost } \\
\text { Curvature } \\
{[6]} \\
\end{array}$ \\
\hline Institutional Factors & & & & & & \\
\hline Corporate Governance & $\begin{array}{c}-0.0424 * * \\
{[-2.346]}\end{array}$ & $\begin{array}{c}-0.0027^{*} \\
{[-1.759]}\end{array}$ & $\begin{array}{c}0.0249 * * * \\
{[3.193]}\end{array}$ & $\begin{array}{l}0.0220 \\
{[1.117]}\end{array}$ & $\begin{array}{c}-0.1738 * * * \\
{[-3.300]}\end{array}$ & $\begin{array}{c}-0.9204 * * \\
{[-2.060]}\end{array}$ \\
\hline Creditor Rights & $\begin{array}{l}-0.0102 \\
{[-0.465]}\end{array}$ & $\begin{array}{l}-0.0042 \\
{[-1.142]}\end{array}$ & $\begin{array}{l}-0.0100 \\
{[-1.571]}\end{array}$ & $\begin{array}{l}0.0411 \\
{[1.187]}\end{array}$ & $\begin{array}{l}0.0324 \\
{[0.503]}\end{array}$ & $\begin{array}{l}-0.0422 \\
{[-0.185]}\end{array}$ \\
\hline Institution & $\begin{array}{l}0.0010 \\
{[0.023]}\end{array}$ & $\begin{array}{l}0.0094 \\
{[0.761]}\end{array}$ & $\begin{array}{c}0.0638 * * * \\
{[3.584]}\end{array}$ & $\begin{array}{c}-0.2332 * \\
{[-1.786]}\end{array}$ & $\begin{array}{c}-0.2343^{*} \\
{[-1.663]}\end{array}$ & $\begin{array}{r}-0.1380 \\
{[-0.238]}\end{array}$ \\
\hline $\begin{array}{l}\text { Product Market } \\
\text { Competition }\end{array}$ & $\begin{array}{r}0.0782 * \\
{[1.885]}\end{array}$ & $\begin{array}{l}0.0005 \\
{[0.076]}\end{array}$ & $\begin{array}{r}-0.0013 \\
{[-0.074]}\end{array}$ & $\begin{array}{r}-0.1008 \\
{[-0.903]}\end{array}$ & $\begin{array}{l}0.1335 \\
{[0.852]}\end{array}$ & $\begin{array}{r}-0.9498 \\
{[-1.633]}\end{array}$ \\
\hline Financial Markets & $\begin{array}{l}0.0001 \\
{[0.356]} \\
\end{array}$ & $\begin{array}{r}0.0000 \\
{[-0.158]} \\
\end{array}$ & $\begin{array}{r}0.0000 \\
{[0.252]} \\
\end{array}$ & $\begin{array}{r}-0.0003 \\
{[-0.498]} \\
\end{array}$ & $\begin{array}{l}0.0029 \\
{[1.291]} \\
\end{array}$ & $\begin{array}{r}0.0063 \\
{[0.586]} \\
\end{array}$ \\
\hline $\begin{array}{l}\text { Observations } \\
\text { R-squared }\end{array}$ & & & & & & $\begin{array}{l}74272 \\
0.496 \\
\end{array}$ \\
\hline
\end{tabular}

Note: The dependent variable is Tobin's Q. This table shows key coefficient estimates on theoretically derived interaction terms in equation (6) and organized in the same manner as in Table 2. However, institutional variables are assumed to potentially affect real investment adjustment. Real factors as well as country and year fixed effects are included but not reported. T-statistics are presented in parenthesis based on robust standard errors clustered at the country-year level: * denotes significant at 10 percent, ** at 5 percent, and $* * *$ at 1 percent. 
Table 7. Instrumental Variable Estimation

a

Required Return -b1

(-) Fin. Friction

Coeff. Ext. Fin. b2

Fin. Friction

Coeff. Capital $-b 3$

(-) Fin. Friction Curvature

\section{Institutional Factors}

Corporate Governance

[1]

[2]

[3]

[4]

\begin{tabular}{|c|c|c|c|c|}
\hline \multirow[t]{2}{*}{ Creditor Rights } & -0.0120 & -0.0009 & -0.0040 & 0.0221 \\
\hline & {$[-0.558]$} & {$[-0.205]$} & {$[-0.623]$} & {$[0.530]$} \\
\hline \multirow[t]{2}{*}{ Institution } & -0.0113 & 0.0022 & 0.0578 & -0.2333 \\
\hline & {$[-0.254]$} & {$[0.129]$} & {$[3.440]^{* * *}$} & {$[-1.291]$} \\
\hline Product Market & 0.0811 & 0.0015 & -0.0215 & -0.1098 \\
\hline Competition & {$[1.968]^{* *}$} & {$[0.162]$} & {$[-1.501]$} & {$[-0.782]$} \\
\hline \multirow[t]{2}{*}{ Financial Markets } & 0.0001 & 0.0000 & 0.0001 & -0.0015 \\
\hline & {$[0.286]$} & {$[0.713]$} & {$[0.390]$} & {$[-1.789]^{*}$} \\
\hline Observations & & & & 74272 \\
\hline R-squared & & & & 0.496 \\
\hline Kleibergen-Paap Wald rk F statistic & & & & 5.14 \\
\hline Anderson-Rubin Wald test & & & & $F(71,607)=165.17$ \\
\hline
\end{tabular}

$[-1.373] \quad[-1.473] \quad[2.321]^{* *} \quad[2.202]^{* *}$

Note: The dependent variable is Tobin's Q. This table shows key coefficient estimates on theoretically derived interaction terms in equation (6) and organized in the same manner as in Table 2. Lagged Q is instrumented by twice lagged Q and interaction terms that involve lagged Q is instrumented by the interaction terms based on predicted Q. Real factors as well as country and year fixed effects are included but not reported. T-statistics are presented in parenthesis based on robust standard errors clustered at the country-year level: * denotes significant at 10 percent, $* *$ at 5 percent, and *** at 1 percent. 


\section{Appendix I. Derivation of the Value Function}

In each period, the timing structure is as follows. Based on the existing capital stock of the previous period, $K^{-}$, and the productivity shock $\varepsilon$ revealed at the beginning of the current period, investment $I$ is determined, real adjustment costs and financial transaction costs are paid, and the new capital stock $K$ is formed immediately. Using the new capital stock, $K$, goods are produced with productivity $\varepsilon$. This timing structure is consistent with the continuous time model of Abel and Eberly (1994) as well as with discrete time models that have short lags between investment expenditure and the productive use of new machines. ${ }^{1}$

Profits are denoted by $\pi\left(K_{t}, \varepsilon_{t}\right)$. Following Hayashi (1982), we model the labor decisions of the firm in a simple manner by assuming that the labor market is competitive with a constantreturns-to-scale production function, $f$, and a competitive wage $o$ such that: $\pi\left(K_{t}, \varepsilon_{t}\right)=\left(1+\varepsilon_{t}\right) f\left(K_{t}, L_{t}\right)-o_{t} L_{t}$, with the usual marginal condition: $o_{t}=\left(1+\varepsilon_{t}\right) f_{L t}$. Similarly, we assume the product market to be competitive. Shocks, $\varepsilon$, to productivity are assumed to have a mean of zero and to be serially correlated with a probability distribution function $P\left(\varepsilon^{+} \mid \varepsilon\right)$, so that a firm which receives a "good" shock in the current period it is likely to have higher profits in the next period as well. ${ }^{2}$

A firm's capital stock depreciates at a rate of $\delta$ and increases with investment, $I$ :

$$
K_{t}=(1-\delta) K_{t-1}+I_{t}
$$

Investment involves real net adjustment costs, $\hat{\phi}\left(I_{t}, K_{t} ; X_{t}, W, \varepsilon_{t}\right)$ which are incurred immediately after the investment is made, but are not included in the law of motion of capital

\footnotetext{
${ }^{1}$ In this formulation, there is no "time-to-build," meaning that firm managers make their investment decisions after the revelation of productivity shocks. This affects both the theoretical dynamics and the interpretations of the estimated coefficients. In particular, both the current and the next period's $Q$ matter for investment. This contrasts with Barnett and Sakellaris (1999), which is a special case of the "time-to-build" model, where there is no equilibrium relationship between current and future values of $Q$. However, as shown above, our empirical results are robust to different timing assumptions.

${ }^{2}$ This feature is similar to the imperfectly competitive market studied by Abel and Eberly (2008), who show that profits (or cash flows) measure rents or "growth opportunities" in some future periods. This situation happens if, for example, a firm creates a very competitive product (e.g., Apple's iPhone).
} 
(A1). In this specification of $\hat{\phi}, X$ denotes fundamental characteristics, which can be timevarying but are assumed to be non-stochastic and predictable (e.g., the industry and age of the firm), $W$ denotes "institutional quality," which is treated as time-invariant and exogenous, in line with the fact that institutional quality is known to be stable over time.

Given the law of motion for capital (A1), the gross adjustment costs of investment can be expressed solely as a function of capital in the current and previous periods. Note that the gross adjustment costs $\phi$ consist of net adjustment costs, depreciation, and investment:

$$
\begin{aligned}
\phi\left(I\left(K_{t-1}, K_{t}\right), K_{t} ; X_{t}, W, \varepsilon_{t}\right) & =\hat{\phi}\left(K_{t}-(1-\delta) K_{t-1}, K_{t} ; X_{t}, W, \varepsilon_{t}\right)+\delta K+I_{t}, \text { if } I_{t}>0 ; \\
& =\delta K_{t}, \text { otherwise. }
\end{aligned}
$$

Following Gomes (2001), we introduce a convex cost function for external finance. Within-period "working capital" finance (using credit lines or trade credit) is assumed to involve no financial transaction costs. However, over-the-period external finance, $B$, is costly; financial transaction costs, denoted by $\hat{\lambda}\left(B_{t}, K_{t} ; X_{t}, W, \varepsilon_{t}\right)$, are incurred when external finance is positive. Overall financial transaction costs, $\lambda$, can also be expressed as a function of the capital stock in the current and previous periods:

$$
\begin{aligned}
\lambda\left(B\left(K_{t-1}, K_{t}, \varepsilon_{t}\right), K_{t} ; X_{t}, W, \varepsilon_{t}\right) & =\hat{\lambda}\left(K_{t}-(1-\delta) K_{t-1}-\pi\left(K_{t}, \varepsilon_{t}\right), K_{t} ; X_{t}, W, \varepsilon_{t}\right), \text { if } B_{t}>0 ; \\
& =0, \text { otherwise. }
\end{aligned}
$$

We assume the firm maximizes the value of capital for all claim holders, both shareholders and creditors. This is in line with most of the literature, which does not distinguish between various sources of financing. Also, in some countries, shareholder value maximization is not always pursued (Allen and Gale, 2000). Consistently, the definition of profit which we use in our empirical analysis, $\pi$, includes the returns to both creditors (interest payments) and shareholders (dividends and retained earnings), as in standard microeconomic theory.

We distinguish between two types of costs. One is the gross adjustment cost of investment, $\phi$, which arises from purely technological issues, not from financing activities. The 
other is the financial transaction costs. This assumption is consistent with many investment models without financial frictions. ${ }^{3}$ Similarly, we do not distinguish between asset types and assume that all assets - tangible, intangible, and cash and equivalents - can generate profits and are subject to financial frictions. In our framework, frictions associated with non fixed capital assets, such as cash, also affect the cost of external finance. For example, if outside investors fear the misuse of internal cash, then the cost of external finance would be higher. ${ }^{4}$

Both the real adjustment costs and the financial transaction costs are incurred at the firm level. In addition, there is also a macroeconomic component of financial frictions (Mussa, 1977), which is reflected in the certainty equivalent of the required rate of return, $r$. This rate is affected by macroeconomic factors, $\theta_{t}$, (e.g., inflation, macroeconomic volatility, etc.) as well as by firm characteristics, $X$. For example, it can differ across industries due to the return covariance structure or across vintages of capital. We therefore include industry dummies and individual firm age in the vector of firm characteristics, $X$. The required rate of return may also vary across countries because of the quality of institutions, $W$, reflecting, for example, weak bankruptcy procedures or the possibility of nationalization. Indeed, one of the main hypotheses we test below is that a good institutional environment is associated with a lower required rate of return.

Overall, we can write the required rate of return, $r$, as a function of three groups of variables, $r\left(\theta_{t}, X, W\right)$. In equilibrium, given the current-period value of the firm, the required rate of return is equal to this period's expected profits minus investment adjustment and financial transaction costs, plus the next-period's expected value of capital:

$$
\begin{aligned}
(1+r(\theta, X, W)) V\left(K^{-}, \varepsilon ; X, W\right) & =\max _{K} \pi(K, \varepsilon)-\phi\left(I\left(K^{-}, K\right), K, \varepsilon ; X, W\right) \\
& -\lambda\left(B\left(K^{-}, K\right), K, \varepsilon ; X, W\right)+E\left[V\left(K, \varepsilon^{+} ; X, W\right) \mid \varepsilon\right],
\end{aligned}
$$

\footnotetext{
${ }^{3}$ In particular, our approach is consistent with Gomes' (2001) model which includes financial frictions, but differs from Hennessy, Levy and Whited (2007) who regard the cost of increasing capital $K$ ( $\phi$ in our case) as the adjustment cost of equity finance and assume a separate cost function for debt finance (corresponding to our $\lambda$ ). In contrast, our framework distinguishes between real and financial transactions costs but not between debt and equity. ${ }^{4}$ In order to examine specifically the cost associated with cash holding, a more narrowly-focused study is necessary, examining issues such as optimal liquidity (e.g., Greenwood, 2005, and Bolton, Chen, and Wang, 2011) or corporate governance (e.g., Dittmar, Mahrt-Smith, and Servaes, 2003, and Almeida, Campello, and Weisbach, 2011).
} 
where, as before, a minus-sign, ${ }^{-}$, denotes one-period past values and a plus-sign, ${ }^{+}$, denotes oneperiod ahead values. Note that both the real adjustment costs of investment and the financial transaction costs can be expressed as functions of the current and previous periods' capital stocks only. Also, the value function (A4) has only two state variables, capital $K$ and the auto-correlated shock $\varepsilon$, in addition to the predetermined firm characteristics $X$ and the time invariant country characteristics $W$. The expectation in the last term is taken over the next-period productivity shocks $\varepsilon^{+}$, given the current-period shock $\varepsilon$.

The first-order condition, assuming positive investment and external finance is:

$$
\phi_{1}+\lambda_{1}=\pi_{1}+\lambda_{1} \pi_{1}-\phi_{2}-\lambda_{2}+E\left[V_{1} \mid \varepsilon\right]
$$

where the terms $\lambda_{1}$ and $\lambda_{2}$ denote the partial derivatives of the financial transaction cost function with respect to the first argument (external finance $B$ ) and the second argument (capital $K$ ), respectively, and, similarly, the terms $\phi_{1}$ and $\phi_{2}$ denote the partial derivatives of the investment adjustment cost function. The envelope condition is:

$$
(1+r) V_{1}^{-}=(1-\delta)\left(\phi_{1}+\lambda_{1}\right) \text {. }
$$

By combining the two conditions, we obtain the Euler equation:

$$
\frac{1+r}{1-\delta} V_{1}^{-}=\left(1+\lambda_{1}\right) \pi_{1}-\phi_{2}-\lambda_{2}+E\left[V_{1} \mid \grave{\mathrm{o}}\right]
$$

The marginal $Q$ is defined as the derivative of firm value with respect to capital,

$$
Q\left(K ; X, W, \varepsilon^{+} \mid \varepsilon\right) \equiv E\left[V_{1}\left(K ; X, W, \varepsilon^{+} \mid \varepsilon\right)\right] .
$$

Using the approximation, $1+r+\delta \approx \frac{1+r}{1-\delta}$, we can simplify the Euler equation to:

$$
(r+\delta) Q^{-}=E\left[Q-Q^{-} \mid \grave{\mathrm{o}}\right]+\left(1+\lambda_{1}\right) \pi_{1}-\phi_{2}-\lambda_{2} .
$$

This equation describes the equilibrium law-of-motion of $Q$ and is almost exactly the same as the one derived by Abel and Eberly (1994). The term on the left-hand-side is the required rate of return on the beginning-of-period marginal value of capital. The right-hand-side is the sum of expected marginal capital gains plus profits, net of the marginal costs associated with investment and external finance. 


\section{Appendix II. Data Description}

We use firm level data from the Worldscope database of Thomson Reuters. The data cover the period 1990 to 2007 for 48 countries, and the sample contains about 380,000 firm-year observations for which $Q$ can be constructed. ${ }^{5}$ We eliminate some observations for a number of reasons, with each criterion applied sequentially to the remaining data set. First, we eliminate observations if values are economically not meaningful (e.g., when values for capital expenditure are negative). Second, on a statistical basis, observations in excess of three standard deviations from the mean for that variable in the U.S. sample are eliminated. Third, we eliminate countries having fewer than 15 non-financial companies per country with non-missing values for $Q$ in the year 2000 (this concerns Egypt, Morocco, Slovakia, Slovenia and Zimbabwe). And fourth, 2digit SIC industries with less than five firms with non-missing values for age and $Q$ in 2000 , as well as all unclassified companies (SIC 99) are deleted. After these deletions, about 300,000 firm-year observations with $Q$ remain. For the regression results, because of the unavailability of lagged $Q$ and other variables, the sample shrinks further, to about 75,000 firm-year observations in the benchmark regression. ${ }^{6}$

Marginal profit, $\pi_{1}$, is measured by the increase in earnings divided by the increase in total assets. For earnings we use a cash flow measure, defined as Net Income before Extraordinary Items and Preferred Dividends + Interest Expense on Debt + Depreciation and Amortization (variable names correspond to those of Worldscope unless otherwise noted).

\footnotetext{
${ }^{5}$ The number of original firm-year observations, including those for which $Q$ cannot be constructed, is about one million, although those without $Q$ may well include inactive firms. The 48 sample countries are: Argentina, Australia, Austria, Belgium, Brazil, Canada, Chile, China, Colombia, Czech Republic, Denmark, Finland, France, Germany, Greece, Hong Kong, Hungary, India, Indonesia, Ireland, Israel, Italy, Japan, South Korea, Luxembourg, Malaysia, Mexico, Netherlands, New Zealand, Norway, Pakistan, Peru, Philippines, Poland, Portugal, Russia, Singapore, South Africa, Spain, Sri Lanka, Sweden, Switzerland, Taiwan, Thailand, Turkey, United Kingdom, United States, and Venezuela.

${ }^{6}$ The firm age variable, described below, reduces the sample size considerably, from about 150,000 to 75,000. Even though firm age can be constructed for about 270,000 observations out of the original one million, the sample for which both $Q$ and age are available is much smaller. We verify the robustness of our results by excluding firm age and estimating the parameters using a bigger sample. Missing values for other variables halve the sample size from 300,000 to 150,000 ; when it is appropriate due to common accounting practices, we replace missing data with zeros (for example, Net Proceeds from Sale/Issue of Common and Preferred Stocks).
} 
Although this measure can be susceptible to tax and other accounting adjustments hiding the true performance of a firm, some adjustments (e.g., tax credits for R\&D expenditures or future losses) are legitimate. Also, taxation matters for firm valuation. Nevertheless, for robustness, we also use a before-tax measure, Operating Income + Depreciation and Amortization.

For investment, I, we use the usual definition of investment - Capital Expenditure in our benchmark regressions. Our broad definition of capital stock also includes cash and equivalents, e.g., holdings of bonds and equity investments in other companies. As a robustness check, we therefore use Capital Expenditure + Change in Cash and Short-Term Investment. Both are assumed to be subject to adjustment costs.

External finance, B, is defined in line with Rajan and Zingales (1998) and others as Capital Expenditure + Change in Cash and Short-Term Investment - Cash Flow from Operation - Decrease in Inventory - Decrease in Receivables - Increase in Payables. We add the change in cash to the original Rajan and Zingales (1998) definition, in line with our broad concept of investment. For robustness, we use a narrower external finance concept excluding trade credit, defined as the net increase in Total Debt + Net Proceeds from Sale/Issue of Common and Preferred Stocks.

We define $Q$ as the Market Capitalization + Total Assets - Total Equity over Total Assets. $Q$ is measured at the end of each fiscal-year, usually right after the ex-dividend date. This measure of $Q$ is commonly used in cross-country empirical studies in the corporate finance literature. As noted, we use Total Assets as our broad measure of capital. The short time dimension of our data - only 16 years - renders more elaborate capital stock calculations based on the permanent inventory method (Blanchard, Rhee, and Summers, 1994) not feasible. Also, debt is valued at par since corporate bond prices are not available for most firms in our sample.

As for firm characteristics, we include industry dummies and firm age (using the variable Founded Date). Firm size is not included as a control variable, because it is endogenous, and depends on financial frictions and investment adjustment costs. Also, several measures of firm size are related to the firm's capital stock, which is used in the regressions as an important variable to identify the effects of institutional and real factors on financial frictions and investment adjustment costs. 
The required rate of return is the sum of the risk free rate and an unobservable risk premium. Our measure of the country-specific real short-term risk free rate is the short-term government Treasury bill rate minus the CPI inflation. To capture country-specific macroeconomic risk factors possibly reflected in the "risk free" rate, we include the CPI inflation rate and macroeconomic volatility, measured as the standard deviation of real GDP growth for the period 1995-2006. CPI and real growth rates come from the World Development Indicators, while short-term Treasury bill rates are from the IMF's International Financial Statistics. We also allow these macroeconomic variables to affect financial frictions (e.g., a higher GDP volatility may lead to a higher cost of external finance). 